\title{
Ivan Skušek Jr. and His Collection of Chinese Coins
}

\author{
Mina $G R \check{C} A R^{*}$
}

\begin{abstract}
Ivan Skušek Jr. (1877-1947), whose collection of Chinese and Japanese objects has been the subject of research and interest in recent years, can be considered the first collector of East Asian objects in the Slovene ethnic space to have built his collection systematically, examining and verifying the provenance, value, and significance of each item. His extensive collection can compare to Western European collections of East Asian objects while at the same time bearing a stamp of local uniqueness pertaining to the European periphery. Skušek's legacy includes an important collection of Chinese money from all periods of Chinese history, which is introduced in this paper for the first time.

A crucial distinction between this and other collections of Chinese coins is that evidence exists that tells us how Skušek collected the coins, and reveals a lot about his sources and advisors. It has long been known that during his stay in Beijing Skušek befriended many influential and knowledgeable people, including a Franciscan missionary, Fr. Maurus Kluge, who assisted him in assembling his numismatic collection. The paper presents the cooperation between the two in the light of a recent find - the original list and summary appraisal of the most valuable part of Skušek's numismatic collection and Kluge's letters to Skušek.
\end{abstract}

Keywords: Ivan Skušek Jr., numismatics, numismatic collection, ancient Chinese coinage, collecting history

\section{Ivan Skušek ml. in njegova zbirka kitajskih kovancev}

\section{Izvleček}

Ivana Skuška ml. (1877-1947), čigar zbirka kitajskih in japonskih predmetov je v zadnjih letih postala predmet številnih raziskav in velikega zanimanja, lahko štejemo za prvega zbiratelja vzhodnoazijskih predmetov v slovenskem etničnem prostoru, ki je svojo zbirko gradil načrtno ter preverjal provenienco, vrednost in pomen vsakega predmeta. Njegovo obsežno zbirko lahko primerjamo z nekaterimi zahodnoevropskimi zbirkami vzhodnoazijskih predmetov, pri čemer jo zaznamuje tudi lokalni pridih evropske periferije. Skuškova zapuščina vključuje tudi pomembno numizmatično zbirko kitajskega denarja iz vseh obdobij kitajske zgodovine, ki je v pričujočem članku predstavljena prvič.

Mina GRČAR, PhD Student and Research Assistant, Department of Asian Studies, Faculty of Arts, University of Ljubljana.

Email address: mina.grcar@ff.uni-lj.si

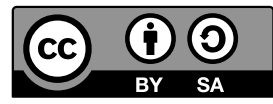


Slednjo od ostalih zbirk kitajskih kovancev najočitneje ločijo pričevanja o načinu, kako je Skušek kovance zbiral, ter o njegovih virih in svetovalcih pri zbiranju. Že dolgo je znano, da se je Skušek med bivanjem v Pekingu spoprijateljil s številnimi vplivnimi in učenimi ljudmi, vključno s frančiškanskim misijonarjem Maurusom Klugejem, ki mu je pomagal pri oblikovanju numizmatične zbirke. Prispevek predstavlja sodelovanje med njima v luči nedavne najdbe - izvirnega seznama in povzetka najdragocenejšega dela Skuškove numizmatične zbirke ter Klugejevih pisem Skušku.

Ključne besede: Ivan Skušek ml., numizmatika, numizmatična zbirka, kitajski kovanci, zgodovina zbirateljstva

\section{Introduction}

Ivan Skušek Jr. (1877-1947) was an outstanding and open-minded collector, enthusiast and visionary. He was one of the most important collectors of East Asian objects who came from the territory of present-day Slovenia. While his extensive and varied collection in its entirety includes objects commonly found in large collections around the world and can compare, at least to some extent, to Western European collections of East Asian objects, it also bears the stamp of local peculiarity and uniqueness pertaining to the European periphery. It is an often neglected fact that Skušek's legacy includes an important collection of Chinese coins originating from all periods of Chinese history, which has never been fully researched and assessed.

The purpose of this paper is to introduce the collection, outline recent work on it, and highlight Skušek's collecting practice, drawing on several recently found documents: a list of Skušek's coins in German, a summary and assessment of his collection - a document titled Summary ("Abridgement" in the original) of $M r$. I. Skušek's Collection of Chinese Coins, to Be Sold Eventually, and letters to Skušek from a Franciscan missionary, Fr. Maurus Kluge. Based on these materials it was possible to identify two key aspects to Skušek's coin collecting, which will be analysed in two separate sections of the paper. The first aspect to be delved into are the types of Chinese coins, which were, according to the letters, particularly interesting and valuable at the time, while specimens of these can indeed be identified in Skušek's numismatic collection. The second aspect to be analysed pertains to the circumstances and ways Skušek collected Chinese coins, which are closely intertwined with his social life at the time of his stay in Beijing.

The author's research into Skušek's collection of Chinese coins is being made within the scope of the VAZ project, the goal of which is to produce the first 
comprehensive and systematic inventory, identification, categorization, analysis, and digitization of the East Asian collections held at various Slovenian museums. We started looking at Skušek's coin collection in 2019 when the international symposium, From Centre to Periphery: Collecting Chinese Objects in Comparative Perspective, was organized by the project team. One of the invited speakers was Dr. Helen Wang, Curator of East Asian Money at the British Museum, who agreed to view the collection and provide us with some basic material to start the research, as well as advise us on ways of examining individual coins.

At the time it was known that Skušek originally kept a list of his entire collection, including his coins, but this was long believed to have been lost. However, in June 2020, several documents were surprisingly rediscovered in a pile of written and printed materials relating to Ivan Skušek Jr. They included four variations of the list of his objects, a list of his coins and the Summary, a document confirming their authenticity, and, perhaps even more unexpectedly, a number of letters from Fr. Maurus Kluge.

The paper is based on the study of Skušek's numismatic collection performed by the author at the Slovene Ethnographic Museum (SEM) with the help of Mag. Ralf Čeplak Mencin, the museum's Curator of Asia and Oceania, the list and the Summary of Skušek's coins, the existing museum inventory book, and Kluge's letters to Skušek. The letters were transcribed from German cursive handwriting into a more legible German and translated into Slovene by Lect. Mag. Niko Hudelja from the Department of History at the Faculty of Arts, University of Ljubljana.

\section{Ivan Skušek Jr., His Stay in China, and His Collecting Zeal}

Ivan Skušek Jr. lived in an outstandingly varied and dynamic era, both for East Asia and the rest of the world. He left home at the onset of modernity, right before the outbreak of WWI, spent his time in China during what was probably one of the most turbulent periods in Chinese history, and returned to Ljubljana to witness a world distinctly different from the one he had left behind seven years earlier. To grasp the significance of his legacy and his vision, it is important to understand the circumstances in which he assembled his collection.

The early 20th century was a period of rapid and radical political, social and economic change for East Asia and Europe, especially the East European periphery that was still ruled by the Austro-Hungarian Empire. In Japan, the Taishō era (1912-1926) followed the sixty years of the Meiji era (1852-1912), which had seen rapid modernization according to the Western model. In China, the 
political and intellectual climate of the late 19th and early 20th centuries was characterized by a profound self-doubt and cultural criticism (Dessein 2014, 50). With the country in political, social and economic turmoil, many progressive Chinese intellectuals advocated the modern ideals of democracy, social equality, personal freedom, and equal rights for women, and demanded the end of certain traditional practices (Saje 2004, 107-13). Meanwhile, cities on the East China coast, forced to open their ports to Western European and American capital, began to evolve into large cosmopolitan hubs, where the traditional and modern intermingled, a new bourgeois class flourished, and increasing numbers of foreign visitors arrived. The socio-political developments in the Euro-American and East Asian space in the late 19th and early 20th centuries thus encouraged contacts and exchange between these parts of the world. Among other things, this situation stimulated the circulation of a range of East Asian objects brought to Europe by travellers, collectors, diplomats, merchants and other individuals who, for various reasons, travelled to East Asia at that time (Vampelj Suhadolnik 2019, 100-103).

Compared to colonial powers such as Great Britain and France, the Habsburg Monarchy, which included the territory of present-day Slovenia, entered the East Asian space relatively late (ibid., 103-105). As the result of both Opium Wars, countries with growing colonial empires (Great Britain, France, Russia, Japan and the USA) acquired trade monopolies and privileges in the defeated China. By the end of the 19th century the race for new colonies and trade monopolies was joined by Germany and the Habsburg Monarchy. In 1897, Germany acquired the port of Qingdao and its hinterland as its concession, as China was forced to cede the territory to Germany for 99 years. While the Habsburg Monarchy did not obtain any colonies in Asia, it did establish stable diplomatic bonds with China, which allowed it to trade there in peace (Čeplak Mencin 2012,101). These circumstances encouraged the first wave of travellers from the Slovene ethnic space to East Asia. We can distinguish several groups of travellers who set out on journeys to East Asia at the time. Most of them were seamen in the service of the AustroHungarian Navy as officers or just ordinary sailors, and served on Austrian warships and merchant ships. They were often joined by Franciscan and Salesian missionaries who ventured to East Asia with the intention of spreading the Christian faith or were driven by a desire to learn about distant places and their cultures. In addition, the missions of Austro-Hungarian ships were often accompanied by diplomats, researchers, scientists and other experts. Meanwhile, with the route of connection having been set, travel to East Asia was also made possible for individual travellers and adventurers (Marinac 2017,14-18). All these groups of people represented a colourful crowd of individuals who, for very different reasons, 
ventured into the distant world of East Asia. They would return home with exciting stories and vivid memories that they would further support with the various curious objects they brought from their trips.

The number, quality and size of East Asian objects that these individuals bought or otherwise collected on their travels were subject to their status, their economic power, and last but not least, the nature of their travels, their personal interests and tastes. Smaller, cheaper items, such as postcards and examples of the so-called export art, intended as souvenirs for foreign visitors, were accessible to ordinary seamen, individual travellers and adventurers. Meanwhile, seafarers of higher ranks, diplomats and various professional associates often had an opportunity for genuine contact with wealthy locals and their lifestyles. In addition, their purchasing power was much higher, so they could afford the purchase and transportation of larger and much more valuable items (Vampelj Suhadolnik 2019, 113-17). Ivan Skušek Jr., an Austro-Hungarian Navy officer, who found himself confined in Beijing during WWI, was a very exceptional man of the latter category. In almost seven years of living in Beijing he became an avid collector and regular visitor to Beijing antique markets, systematically and enthusiastically assembling his collection. He returned to Ljubljana in 1920 with an impressive collection of precious items and collector's rarities from China, which is now held by the Slovene Ethnographic Museum.

Ivan Skušek Jr. was born on June 17, 1877, in Metlika, as one of four children of Ivan Skušek Snr., an Austro-Hungarian tax officer. After finishing his studies, he joined the Austro-Hungarian Imperial Navy, where he was soon promoted to naval officer of the first rank. After a number of voyages across the Mediterranean, the Black and Red Seas, he was employed as an official at the Ministry of War in Vienna. In July 1913, he boarded the Austro-Hungarian cruiser SMS Kaiserin Elisabeth as an intendant (accountant, cashier and economist). The ship left the port of Pula, bound for Japan, and arrived at the German concession of Qingdao on the Chinese coast on July 22, 1914 (Čeplak Mencin 2012, 98-99).

In Europe, WWI broke out on July 28, 1914. Shortly after that, on August 23, Japan declared war on Germany, demanding that it cede the port of Qingdao to Japan. The SMS Kaiserin Elisabeth with her 12 officers, including Skušek, and 240 seamen, had to join the German forces in Qingdao. Kaiserin Elisabeth sank on November 3, 1914, after weeks of fighting (ibid., 102). The conflict was resolved with the German and Austrian surrender and Qingdao fell into Japanese hands. The defeated German and Austrian soldiers were taken into confinement in Japan, while their officers, including Ivan Skušek, were taken into confinement in Beijing. Skušek must have arrived in Beijing by the end of November and retained his 
position of chief intendant officer even though he was confined, being in charge of supplying food and other necessities for his fellow officers in confinement. For this reason, he was issued a pass that enabled him to exit the confinement camp and move freely around Beijing. As he walked the streets of Beijing, he must have noticed the abundance of small antique stores that sold cheap, accessible Chinese antiquities of all sorts. He also knew how to make money when purchasing necessities for the officers, which enabled him to start buying and collecting a variety of objects (ibid., 101-105). Living among the higher social strata of Westerners in the diplomatic quarter in Beijing, Skušek met a number of interesting people of different nationalities, and built connections with knowledgeable and influential individuals, which in turn helped him to access and purchase larger and more valuable objects for his collection.

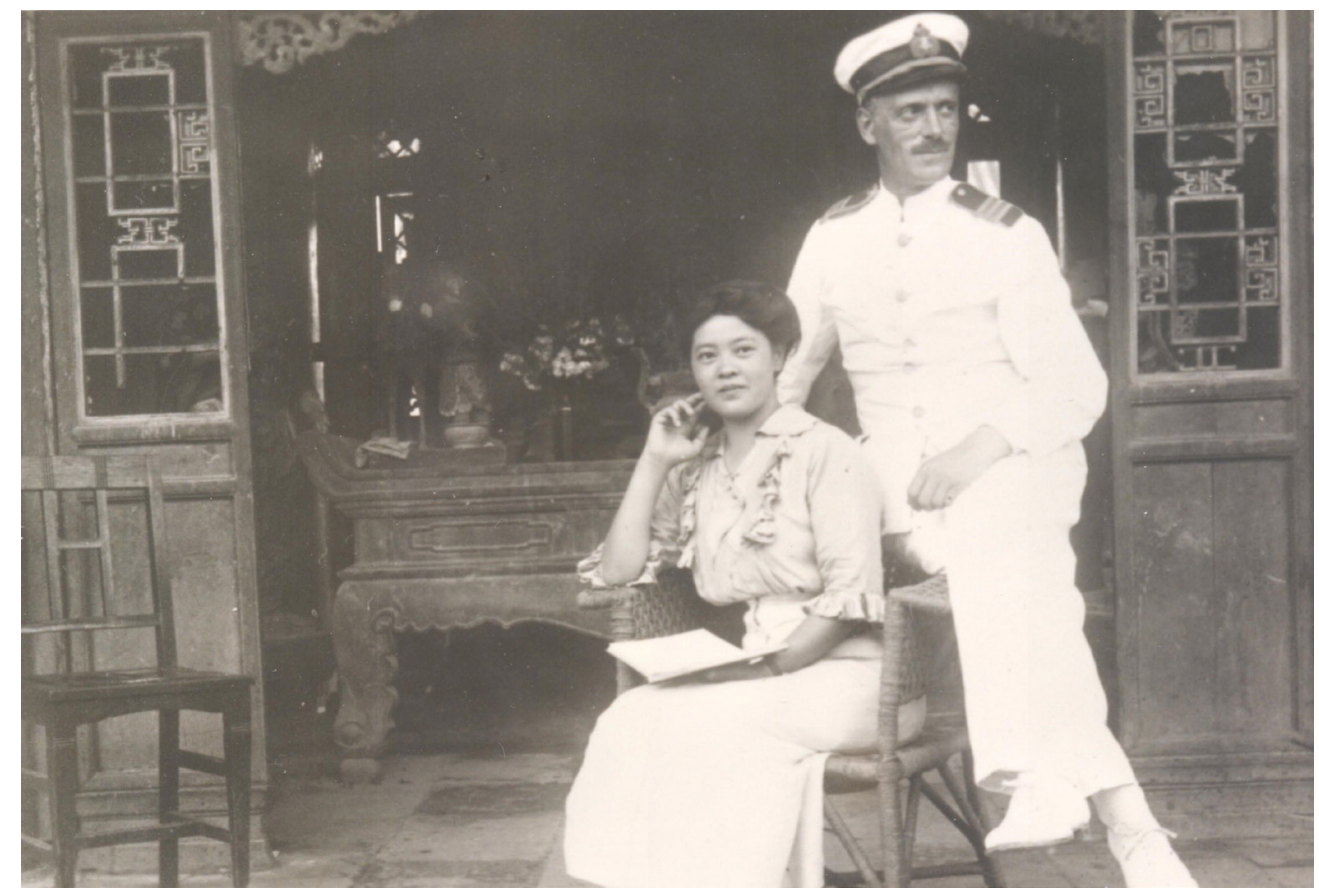

Figure 1. Ivan Skušek and Tsuneko Kondō Kawase in Beijing, between 1918 and 1920. (Source: Photo Archive of the Slovene Ethnographic Museum, Ljubljana; the original is kept by Janez Lombergar, Ivan Skušek Jr.'s grandnephew)

During his years in Beijing, Ivan Skušek also met a young Japanese woman, a florist, who would become his wife, Tsuneko Kondō Kawase (1893-1963) (fig. 1). Tsuneko had been married to a German chief customs official, Paul Heinrich Schmidt, 
and had two children with him, a son Matthias (1912-1933) and a daughter Erika (1914-1958). By the time she met Ivan Skušek, she obviously no longer lived with Schmidt, who had left the family for reasons unknown to us. Skušek married Tsuneko on June 12, 2020. The family first visited Tsuneko's mother in Japan, then returned to Beijing where he prepared his precious antiquities for transportation, before the four of them left for Europe. They finally reached Ljubljana on September 8,1920 , with numerous crates of valuable objects arriving a little more than a month after the family (ibid., 109-11).

The cases contained enormous quantities of precious, rare Chinese antiquities and works of art: paintings, sculptures, ceramics and porcelain, lacquered objects, textiles and other items of clothing, hats and footwear, musical instruments, coins, fans, snuff bottles, tobacco and opium pipes, and other objects for everyday use, larger objects such as furniture, large ceramic garden sets and architectural models, as well as books, albums, photographs and postcards. Among other things, Skušek can be considered one of the first Westerners to be interested in Chinese furniture: he developed an artistic appreciation of its elegant lines and richly carved motifs and started treating pieces of furniture as precious collecting items (Vampelj Suhadolnik 2020, 53-54). Most of the objects in the collection date from the Qing dynasty (1644-1912), with quite a few of them very likely originating from the Forbidden City (Čeplak Mencin 2012, 105, 113-15).

When buying in Beijing antique shops and assembling his collection, Skušek was driven, among other things, by the desire to establish a museum of Chinese culture in his homeland. His vision was to bring the cultural, civilizational, and technological achievements of China closer to his fellow Slovenes and dispel the mostly negative stereotypes about the Chinese that were prevalent in the media at the time. Unfortunately, his plan never materialized due to financial constraints (Vampelj Suhadolnik 2019, 115-16). Insisting on keeping the collection as a whole, Ivan Skušek stored most of the objects in his and Tsuneko's apartment in Ljubljana and bequeathed the entire collection to the National Museum, which later handed it over to the Slovene Ethnographic Museum (Čeplak Mencin 2012, 115). After his passing in 1947, the collection remained in their family apartment until Tsuneko's death in 1963. In his written memoir, Franci Skušek recorded what his brother Ivan had told him about his stay in Beijing. His records mention that Ivan kept a detailed list of all the objects in the collection, along with the prices in Chinese dollars he paid for them. However, the list was believed to have been lost soon after the collection arrived in Ljubljana. 
After its arrival at the Slovene Ethnographic Museum in the 1960s, the collection, including the numismatic assemblage, was partly inventoried by Dr. Pavla Strukelj (1921-2015), the previous curator of the museum collection. Unfortunately, the inventory was never completed nor was the collection thoroughly researched until the VAZ project was initiated in 2018. Research and reconstruction of the original collection would have been a lot easier with the list of objects mentioned by Franci Skušek, but it was not available. In 2020, exactly one hundred years after Skušek's return and the arrival of the collection in Ljubljana, several documents were discovered by chance among other written materials related to Skušek (Berdajs 2021, 144-45). ${ }^{1}$ They included four versions of Skušek's list of objects, although these do not mention the prices of items like the original list supposedly did. However, they do cite numerous precious pieces of porcelain, silk garments, lanterns, furniture and other visually arresting artefacts most of which had been known to have belonged to Skušek. Meanwhile, the newly discovered documentation even included materials pertaining to Skušek's collection of Chinese coins, probably the most unresearched part of his legacy to date. These encompassed a detailed list of Chinese coins in German as well as a summary and assessment (the Summary) of the same coins in English, confirming their authenticity and signed by Skušek himself. Another precious find was a number of handwritten letters from the missionary Kluge to Ivan Skušek that reveal a great deal of hitherto unknown facts about Skušek's stay in Beijing and the nature of his collecting practices, especially those related to numismatics. The letters give us a breakthrough and insight into Skušek's collection of Chinese coins.

\section{Chinese Numismatics in China and Europe}

In the most general sense of the word, numismatics is the study or collection of currency, including coins, tokens, paper money and related objects. The history of coin collecting might be as long as the history of using coins as currency. In Europe, according to some sources, Caesar Augustus collected old Roman coins as early as the 1st century BC. Meanwhile, Petrarch is credited as the first Renaissance collector. Coin collecting started to emerge as a popular pastime of European royalty and nobility, which is why numismatics is often called the "hobby of kings". Numismatics as a field of systematic research began to flourish in the 18th and especially 19th centuries, when the first professional numismatic societies began to emerge (Yu and $\mathrm{Yu} 2004,2)$.

1 The life and collection of Ivan Skušek Jr. are also discussed by Klara Hrvatin (2021) and Nataša Visočnik Gerželj (2021) in this volume. 
Numismatics may have an even longer tradition in China, which is not surprising with regard to the long and varied history of Chinese currency that spans more than 3,000 years. The earliest known catalogue of Chinese coins, Quanzhi 泉志 by Hong Zun 洪遵 (1120-1174), published in 1149, was probably the first numismatic catalogue in the world (Wang 2012, 417). Collecting and researching coins was a scholarly pursuit, and Chinese numismatics flourished in the late 19th century, especially in the field of the "inscriptions on metal and stone" (jinshixue 金石學), with scholars sharing not only their knowledge, but also rubbings of coins in their collections (Jankowski 2018, 119-49). Numismatics continued to develop in the first half of the 20th century, at the time Skušek was staying in Beijing. Even the great literary modernist Lu Xun 魯迅 (1881-1936) researched Chinese coins during his employment at the Ministry of Education, while working on the restoration of the Imperial Library and the plans for the Museum of History. He bought coins in the antiques market, researched numismatic works, and as one of his manuscripts from 1913 reveals, intended to extend Hong Zun's Quanzhi from the 12th century down to the 19th century (Wang 2012, 417-18).

Despite its prominence in China, Chinese numismatics as a field of study still seems to be somewhat obscure in the Euro-American space. The earliest European work on Chinese money was probably Marco Polo's (c. 1254-1324) famous description of Chinese paper money, which is often considered as evidence that he did actually go to China. From the 1700s on, when cultural and trade contacts between East Asia and European colonial centres were established, it was mostly merchants, forgers, academics, missionaries and other individuals who took interest in the study of Chinese money. Even in the 18th and 19th centuries people studying Chinese coins in the West still came from very different walks of lifesinologists, missionaries, merchants, doctors, surgeons, botanists, officials, bankers, military men, explorers, aristocrats and others-each with their own interests and motivations. Along with the development of numismatics as a field of scientific research and the establishment of professional numismatic societies, more people took interest in Chinese money and started collecting Chinese coins purely from a scholarly perspective. By the end of the 19th and the beginning of the 20th centuries, some important collections arrived in Europe and the United States. At the time, significant contributions to Chinese numismatics and numismatic collections in Europe were made by Westerners living and working in China for various reasons (ibid., 399-415).

As a European collector of Chinese coins, Skušek belongs to a group of people who were often quite distinguished in their particular fields in China, but generally not known for their interest in coins. As with the practice of collecting East 
Asian objects in general, the field of Chinese numismatics in the West has been mostly limited to the former colonial centres, while it never developed to such an extent in other, peripheral regions of Europe. This makes Skušek's collection all the more remarkable.

\section{Description and Scope of Skušek's Collection of Chinese Coins}

Although Ivan Skušek's numismatic collection was partly inventoried by Dr. Štrukelj in 1966, it has never been properly examined and assessed. In 2019, we decided to tackle it within the VAZ project, starting with the coins listed in the inventory book, since only these can be confirmed to have belonged to Skušek. According to the inventory by Dr. Štrukelj, Skušek's collection boasts an assemblage of at least about $216^{2}$ Chinese coins and other types of ancient Chinese money. The specimens included originate from almost all periods of Chinese history, ranging from spade (bubi 布幣 or buqian 布錢) and knife coins (daobi刀 幣 or daoqian 刀錢), ant-nose money (yibi qian 蟻鼻錢), often called ghost's or death's face money (guilian qian 鬼臉錢), dating from the Zhou dynasty (1046$221 \mathrm{BC}$ ), to round coins with a square hole, fangkong qian 方孔錢 or cash coins, which were the standard form of coins from the Qin dynasty (221-206 BC) to the end of the Qing dynasty. The collection even contains several exquisite and extremely rare coins from the Wang Mang 王莽 (reigned 9-23) period. As in most Western collections of Chinese money, the majority of the coins originate from the Qing dynasty, including the so-called "rebel coins". The latter include coins issued in the early Qing dynasty by the rebellious military leader Wu Sangui 吳三 桂 (1612-1678) in 1674, and later by his grandson and successor Wu Shifan 吳世 璠 (1663-1681) in 1679, as well as coins minted and circulated in parts of China under the Taiping rule during the years of the Taiping Rebellion (Taiping Tianguo yundong 太平天國運動) (1850-1864). There are also two silver commemorative coins from the early 20th century portraying President Yuan Shikai 袁世凱 (1859-1916) (Summary 1946). Additionally, there are some strings of coins and silver ingots, and at least one coin-sword or bixie jian 辟邪劍 from the Qing dynasty, all confirmed to be part of Skušek's collection as well.

The discovery of a typed list of Skušek's coins in German (figs. 2 and 3), the Summary (figs. 4 and 5), and the letters from Fr. Kluge provide useful supporting

2 The 216 coins bear the inventory numbers from the Slovene Ethnographic Museum (the Goričane Museum) and are listed in the inventory book by Dr. Pavla Štrukelj, which confirms they were definitely part of Skušek's collection. It is possible that some other groups of coins (the Slovene Ethnographic Museum keeps about 1200 Chinese coins altogether) belonged to him as well, but this has not been possible to confirm to date. 
material, invaluable in the process of researching the collection. The Summary document found alongside the German list cites 123 coins of types that correspond to the coins on the list and confirms their authenticity. We can read on the final page of the document: "All pieces are real coins; for example, there are no amulets; the collection covers a period of more than 3,000 years and includes some of the most remarkable types of Chinese coins" (Summary 1946). The text further highlights rare pieces, such as "spade money and ghost's face coins [i.e. ant-nose coins]", which "are known in the numismatic literature as extremely rare; one can find them only by chance" (Summary 1946). The Summary is typed in English and was signed by Ivan Skušek on June 30, 1946 (the year before he died), at Strossmayerjeva Street in Ljubljana, where the family lived after WWII (Motoh 2021, 135). Did he intend to sell his coins? What seems likely as well is that he wished, for some reason, to have this part of his collection officially documented and assessed.

Even more remarkably, the items from the list and the Summary correspond exactly to the 123 coins listed in the 1966 inventory by Dr. Strukelj, which seem to suggest that Dr. Strukelj still had Skušek's lists or the Summary available when she inventoried the coins. The remaining 93 coins in the inventory book include some rare specimens of spade and knife money, round huanquan 环钱 money or "ring coins" from the Zhou dynasty. Why did Skušek not include these coins in his Summary? For the time being, it is still hard to answer this question with certainty. Perhaps he only included those coins that he knew to be authentic.

With this possibility in mind, we are faced with another, essential question pertaining to Skušek's numismatic legacy. How was he able to collect such a representative collection of Chinese coins from all periods of Chinese history? And where did he acquire so much knowledge of Chinese coins? These are the questions that can be answered, at least to some extent, on the basis of the letters written to Skušek by the missionary that he became acquainted with during his stay in Beijing, and who helped him with his numismatic collection. However, that person remained a somewhat mysterious figure until the remarkable discovery in June 2020 - the letters that revealed his identity as Father Kluge, as well as unveiled the nature of their association and cooperation on their Chinese coin collections. 


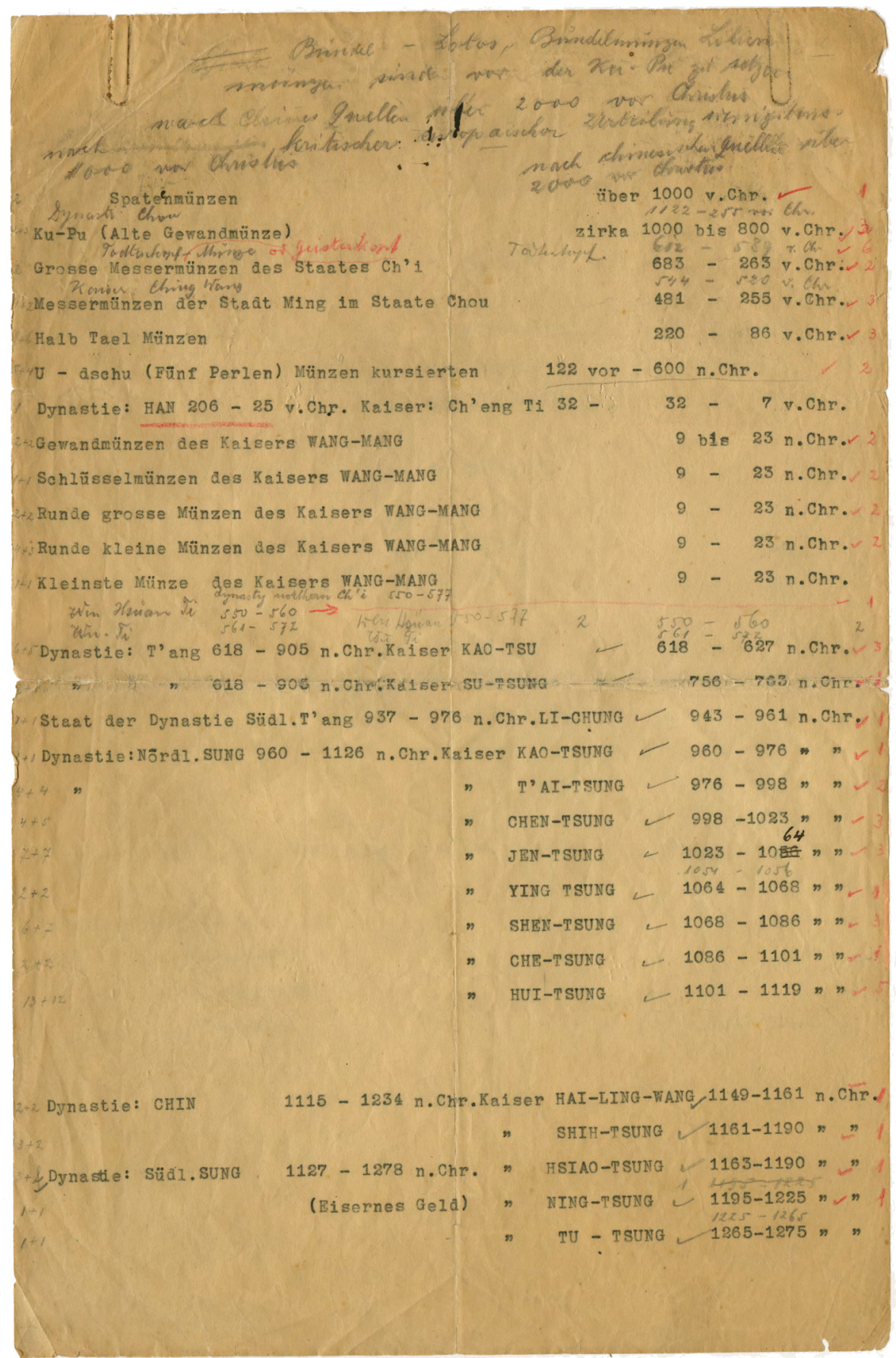




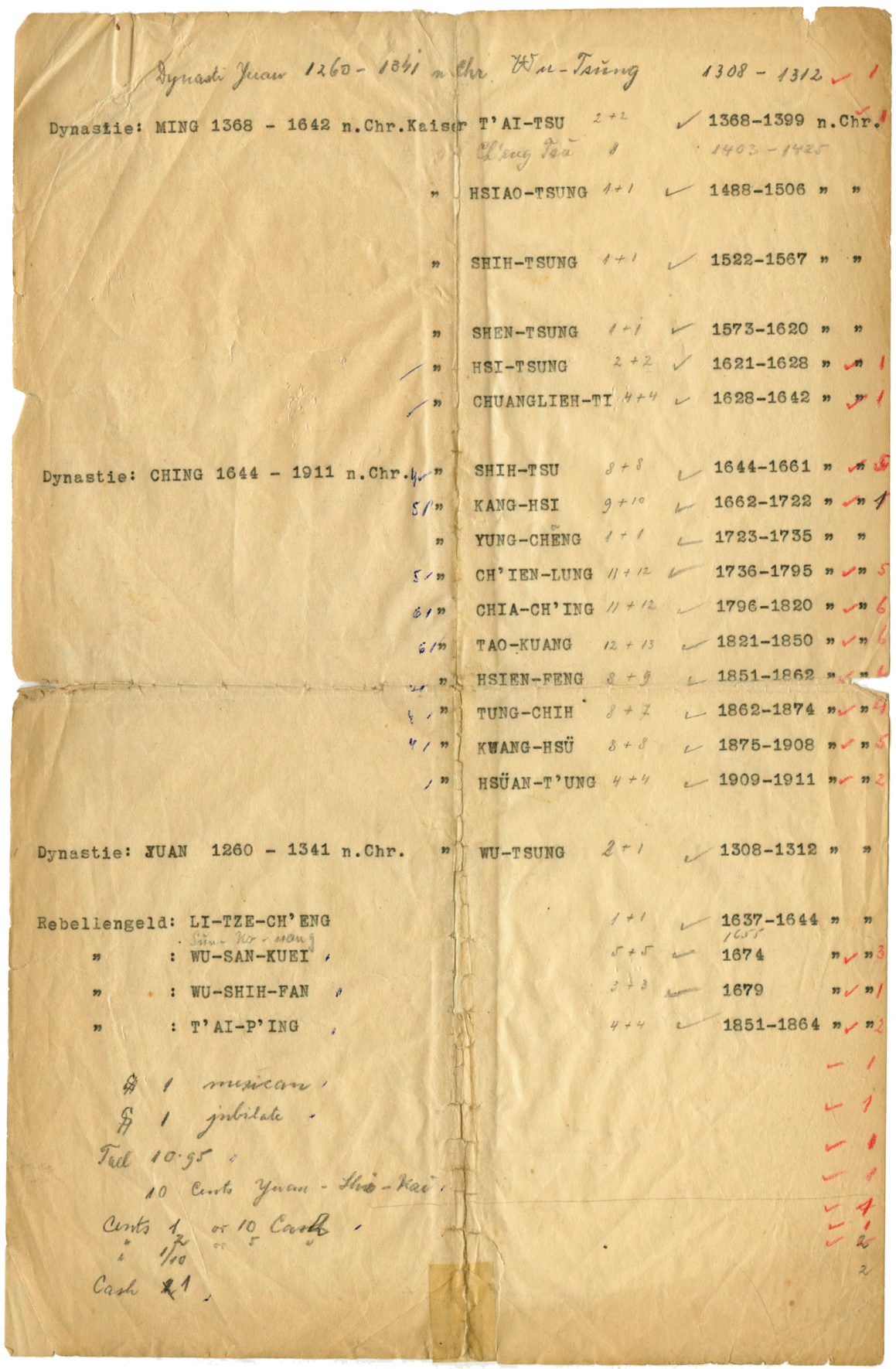

Figures 2 and 3. A list of Skušek's coins from various periods of Chinese history, written in German (possibly prepared by Fr. Maurus Kluge). Photo by the author. (Archive ofthe Slovene Ethnographic Museum, Ljubljana) 


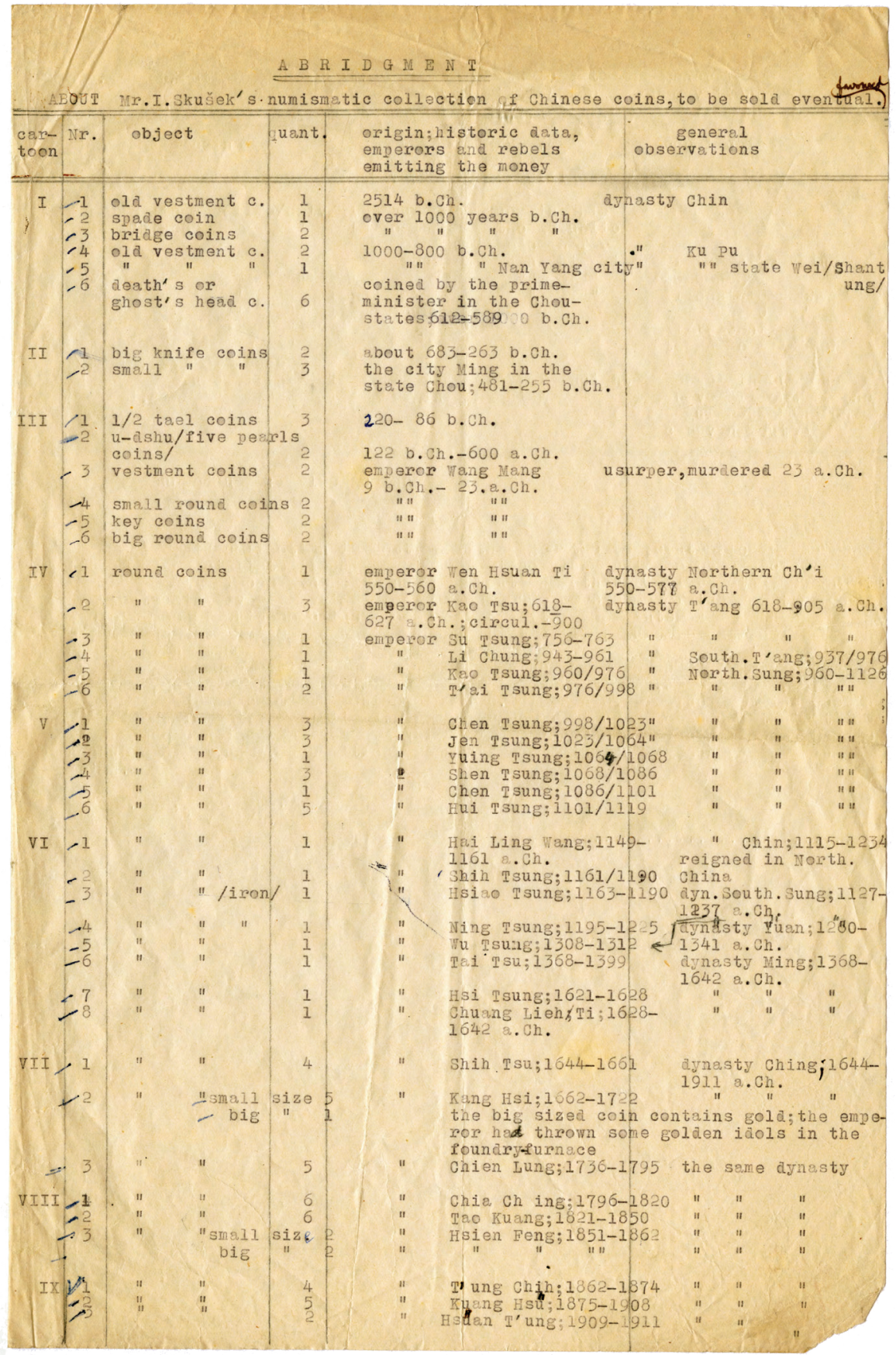




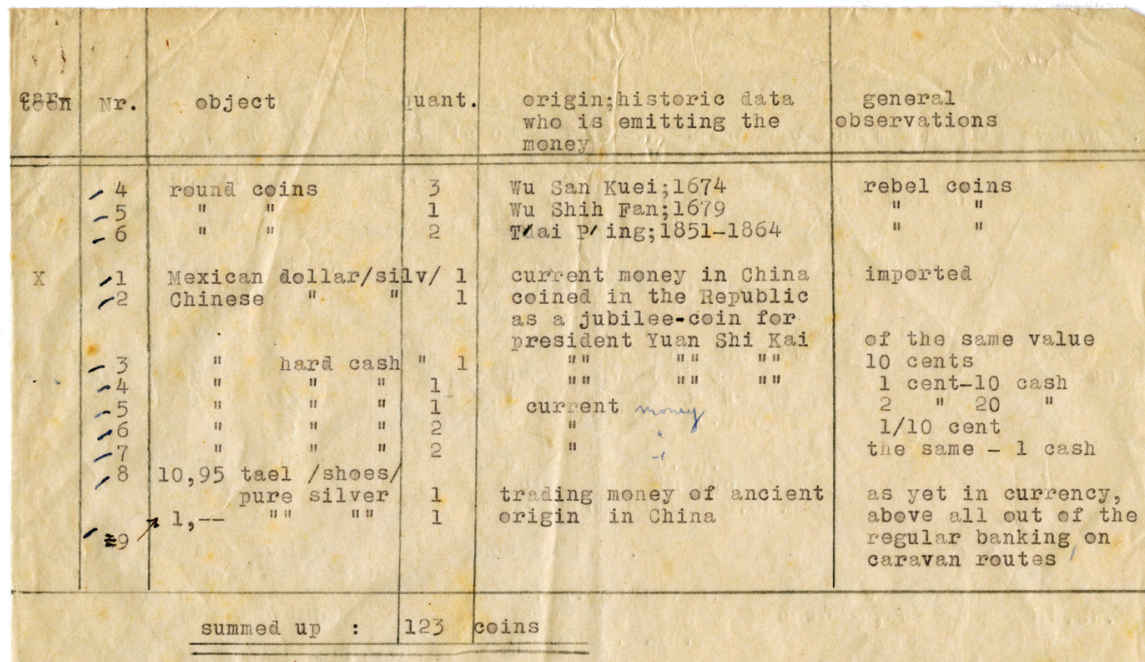

This collection is settled with a great care, controlled by scientists and specialists in China yet so that no blunder is to be expected.

All vieces are real money without any other similar coins as anulet e. extending over a poriod of morelthan 3000 yeres some of the most renarkabie types of Chinese coins are exposed in it.spade mints and death's or ghost's heod coins are known in the numismatic literature as extremely rare; one eon find them by haphazard only.

A landmerk in Chinds history is the Northern sung aynasty regorging politics, geographical conditions, andubesux arts"Mongolia, Japan, mnam, If ia. paxtialy perteine to that/chinese empire. This dynasty is the most interestin one for numismatic specialists. Some onperors of it usea to change their titles during the continuel period of their reign; mong them, defunct engerons become honourea as "Tsung". Such titles are ninted on coins during Sung's and Ming's reign.-

Ijubljana, 30.6.1946.

Strossuderjeva $3 / I$.

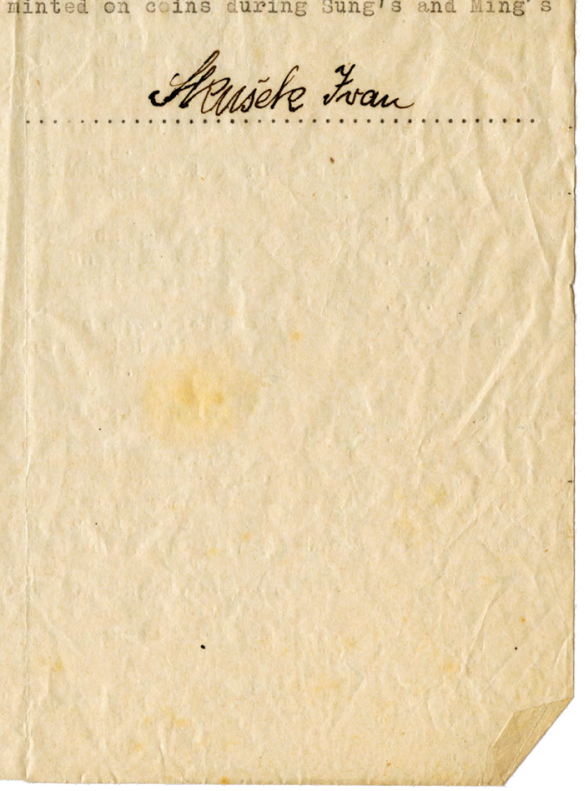

Figures 4 and 5. Summary of Skušek's numismatic collection of Chinese coins, written in English and signed by Ivan Skušek Jr. on June 30, 1946, in Ljubljana. Photo by the author. (Archive of the Slovene Ethnographic Museum, Ljubljana) 


\section{Skušek and His Acquaintance with Fr. Kluge}

There is a total of nine letters written by Kluge in a neat German cursive and addressed to Ivan Skušek. They span the period from November 17, 1918, the time shortly after WWI and the surrender of the Austro-Hungarian Empire (November 11, 1918), to December 31, 1919. To date, only Kluge's letters to Skušek have been found, but these are eloquent enough for us to discern the context, nature and topics of their correspondence. The letters give us a genuine insight into the post-WWI circumstances as experienced by foreigners in China, and reveal new information about Skušek. For example, all of the letters were addressed to Kommissar Ivan Skušek in the Dutch Legation-at that point, he was apparently an employee at the Dutch Embassy. While his name on the envelopes is often written as Kommissar Ivan Skušek (fig. 6), Kluge always starts his letters with a very respectful address, greeting him as "Your Excellency, Dear Mr. Skušek!" (Hochgeehrtester, lieber Herr Skušek!).

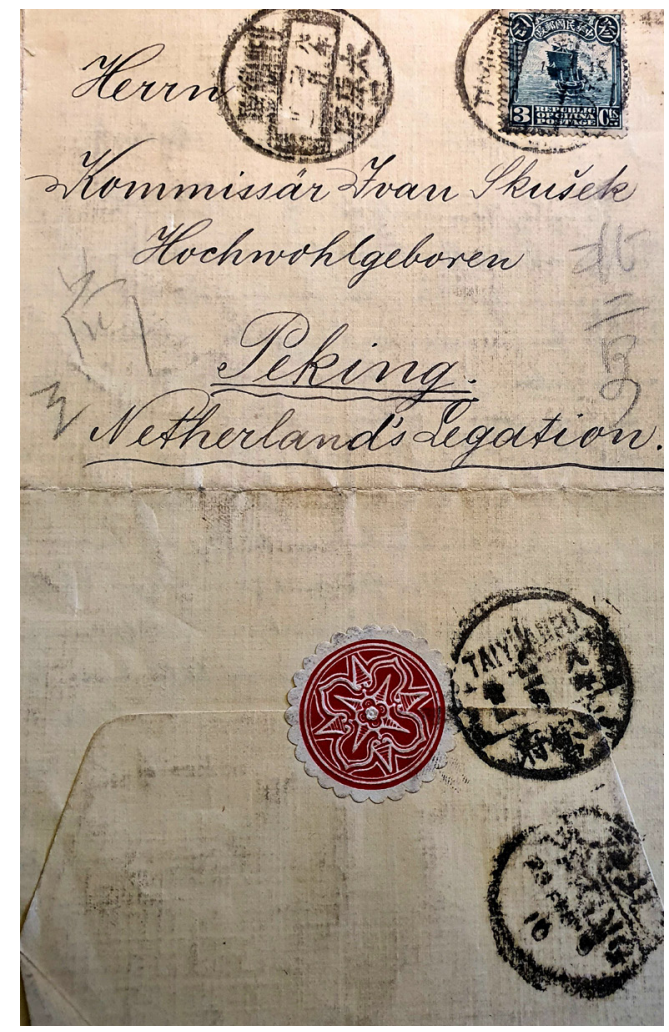

Figure 6. An envelope containing a letter from Kluge addressed to Kommissar Ivan Skušek as an employee of the Dutch Legation. Photo by the author. (Archive of the Slovene Ethnographic Museum, Ljubljana) 
The closing greetings in the letters reveal that Skušek was still accompanied by his subordinate officer Lieutenant Gayer at the time. Kluge concludes the letters "With best wishes to you and Mr. Gayer" (Mit besten Grüßen an Sie und Herrn Gayer). In the letter written on January 24, 1919, he also adds "the good Mrs. Schmidt" (die gute Frau Schmidt) to his final greeting, while two later letters, dated February 15 and March 4,1919, even mention her children: "With the most cordial greetings to you, Mr. Gayer and the good Mrs. Schmidt and her two little children" (Viele recht herzliche Grüße an Sie, H. Gayer und die gute Frau Schmidt u. Ibre beide Kinderchen).

The letters are always signed as "Your devoted" (Ihr ergebenst) or "Your most devoted" (Ihr ergebenster) "Fr. M. Kluge" [Father Maurus Kluge] (fig. 7). Furthermore, they always cite the Catholic Mission of Taiyuan (Tai-yuan-fu (Shan-si), (Cath. Mission)) as the location of writing (fig. 8), which leads us to assume that he was a Franciscan belonging to the Taiyuan Diocese (Tianzhujiao Taiyuan jiao$q u$ 天主教太原教區), predecessor of the present-day Taiyuan Archdiocese (Tianzhujiao Taiyuan zongjiaoqu 天主教太原總教區) in Shanxi Province.

According to Dr. des. Thomas Richter from the Library of Internationales Katholisches Missionswerk in Aachen ${ }^{3}$, Father Maurus Kluge was indeed a Franciscan missionary who worked in Northern China in the early 20th century (fig. 9 shows his file-card from the Internationales Katholisches Missionswerk library). Born on October 5, 1873, in Silesia, archdiocese of Breslau/Wroclaw, he became a member of the Franciscan order (OFM) in 1892 and was sent to China in 1912. He boarded the S.S. Derfflinger, bound for China, which left Naples on January 10, 1913. He worked in the Taiyuan diocese in Northern Shanxi for many years, including the time he was in touch with Skušek. It is very likely that he occasionally travelled to Beijing, which can be conjectured on the basis of his letters to Skušek, in which he mentions his "visit to the camp" (mein Besuch im Lager) (probably the confinement camp in the diplomatic quarter) several times. However, no detailed information on his trips or stays in the capital could be found in the library archives. ${ }^{4}$

3 To establish Kluge's identity, we contacted the Monumenta Serica Institute in Bonn/Sankt Augustin, known for its extensive library on Chinese culture and archaeology, including the contributions to the field by various missionaries who lived and worked in China in the past. Dr. Dirk Kuhlmann from the library of Monumenta Serica Institute and his colleague, Dr. Barbara Hoster, kindly helped us contact the Internationales Katholisches Missionswerk (Pontifical Mission Society/Oeuvre Pontificale Missionnaire) in Aachen and the director of its library, Dr. des. Thomas Richter. The library holds abundant materials on different Catholic orders in Germany, including a large card index of approximately 12,000 file-cards on German missionaries. The cards contain information on missionaries born between 1850 and 1920, most of whom were members of religious orders and natives of the German dioceses (i.e. the Germany of 1871, excluding Bavaria, and sometimes also including dioceses in the Austro-Hungarian Empire, such as Litomerice, Prague, or Olomouc). They were written by the former librarian, P. Franz Baeumker (1884-1975) who collected pieces of information from various journals. One of these file-cards indeed concerned Father Maurus Kluge (fig. 9).

4 Personal correspondence with Dr. des. Thomas Richter, director of the Internationales Katholisches Missionswerk library, November 2020. 
64 Mana GRČar: Ivan Skušek Jr. and His Collection of Chinese Coins

Tai-yuan-Uu (Sha nisi) sun F. tee. 1918.

(bash. Mission).

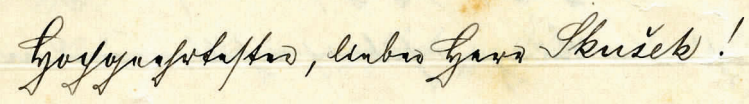

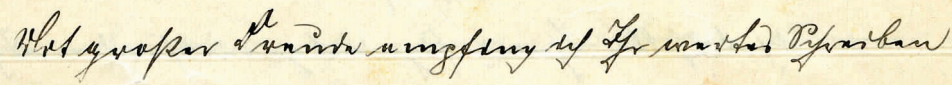

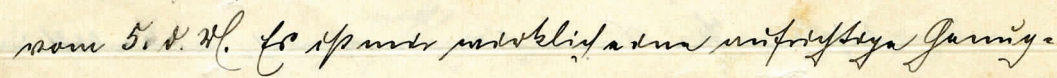

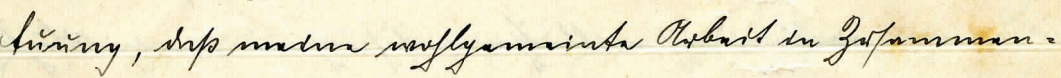

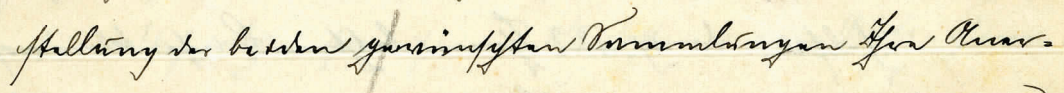

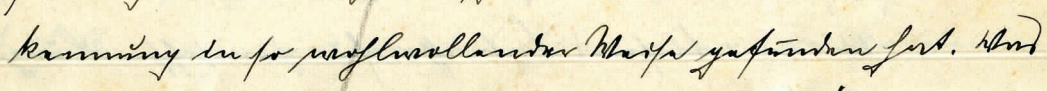

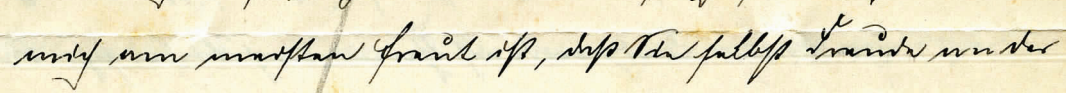

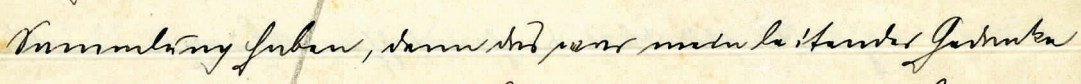

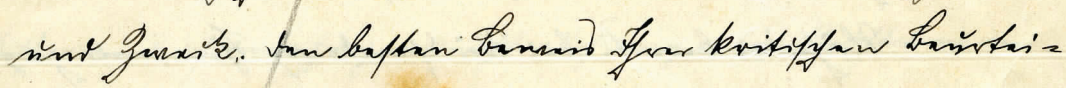

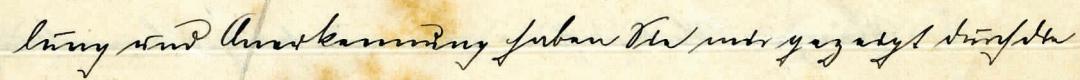

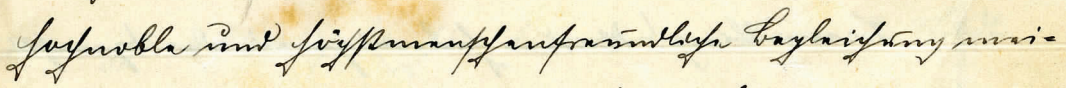

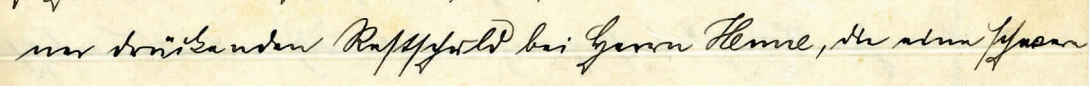

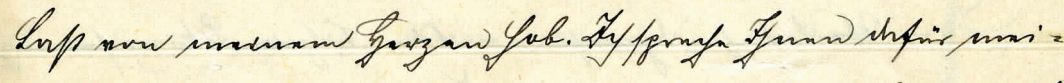

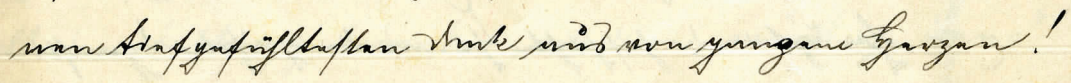


Asian Studies IX (XXV), 3 (2021), pp. 47-83

65

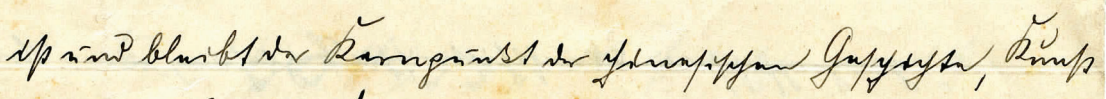

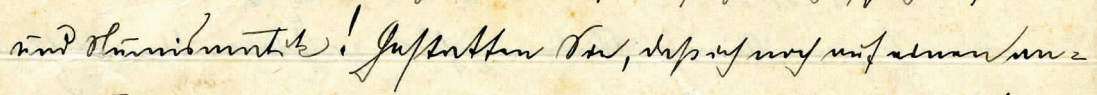

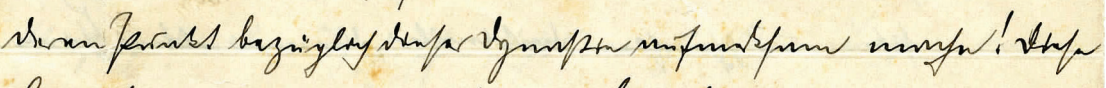

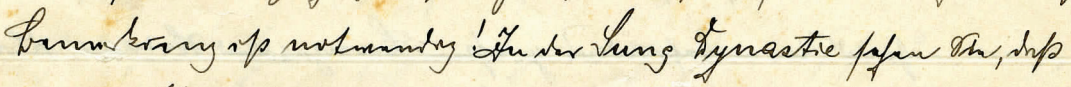

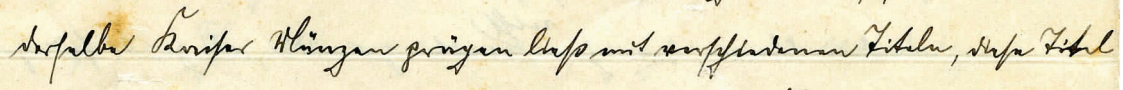

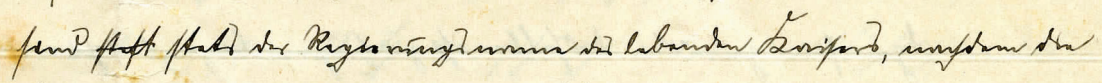

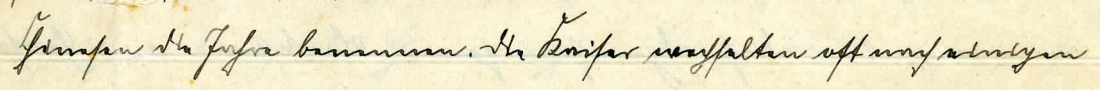

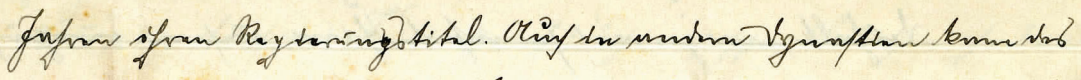

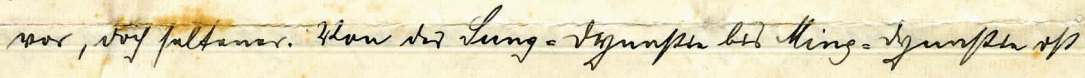

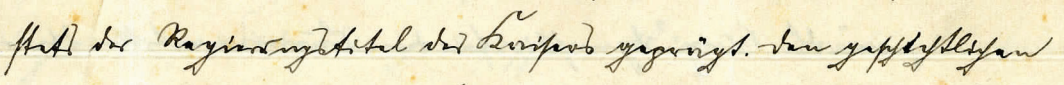

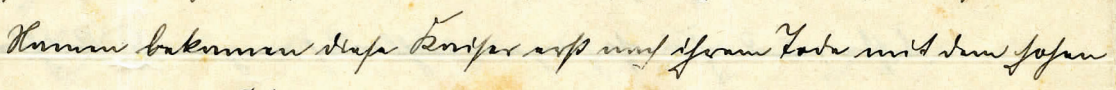

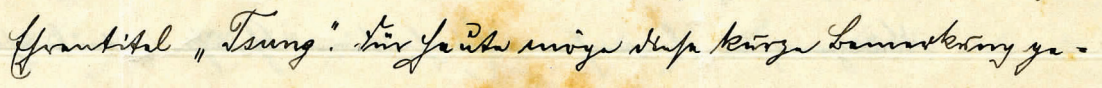

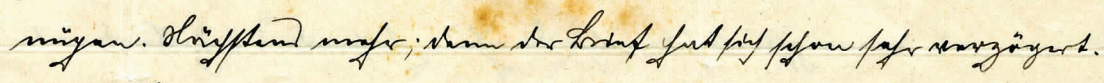

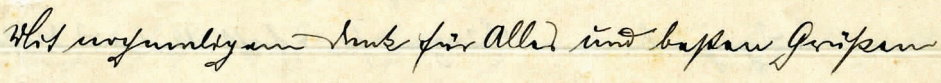
on tin in vo Germ Gayer

Ie argatompar

So. Tenge.

Figures 7 and 8. The opening and final pages of one of Kluge's letters to Skušek, written on December 7, 1918. Photo by the author. (Archive of the Slovene Ethnographic Museum, Ljubljana) 


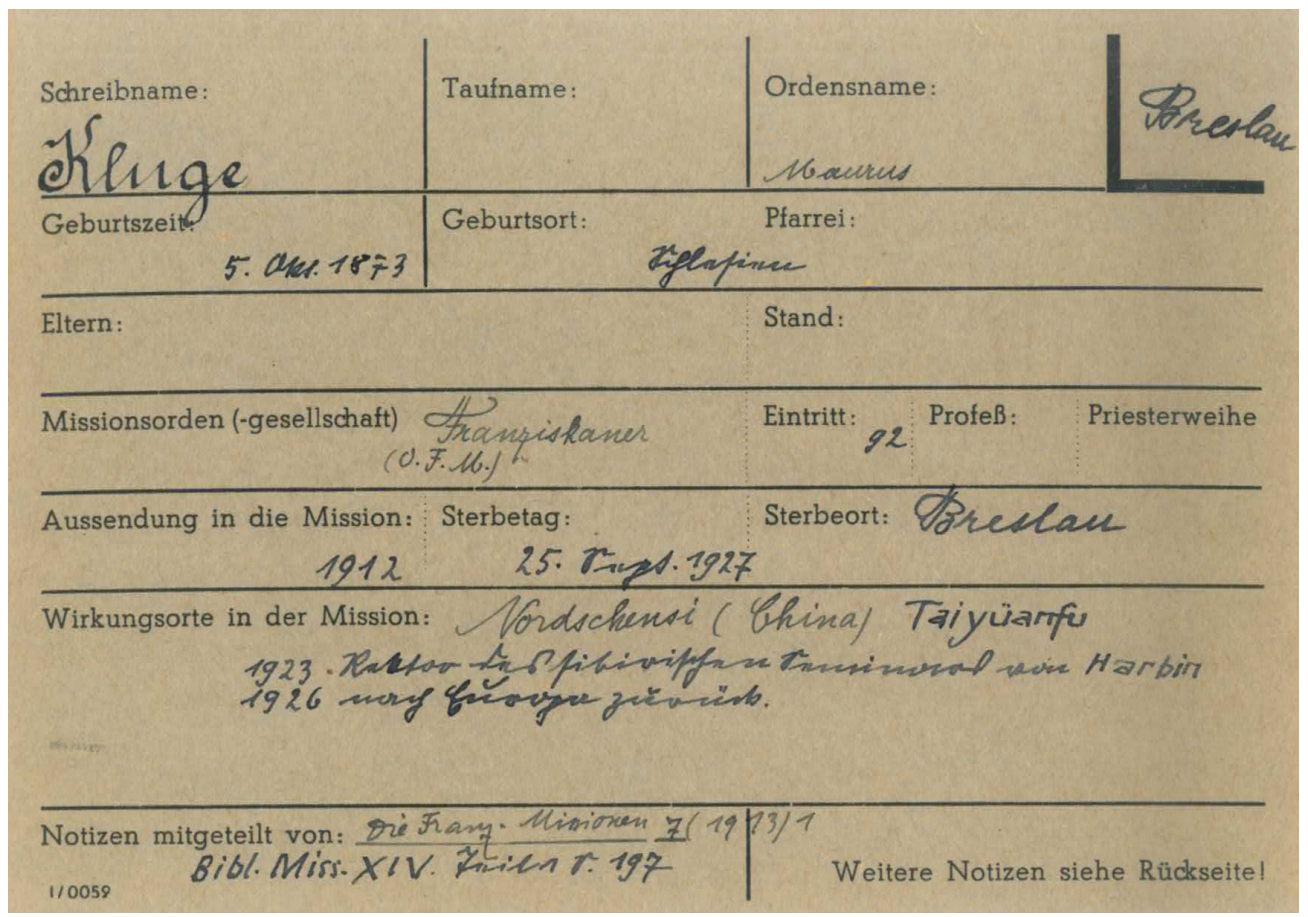

Figure 9. The file-card on Fr. Maurus Kluge. (Source: Internationales Katholisches Missionswerk e. V., Pontifical Mission Society/Oeuvre Pontificale Missionnaire Library, Aachen)

On the basis of the information provided by the Internationales Katholisches Missionswerk, we learned that Kluge was in fact not German, but rather Polish. This confirms the information contained in his letters to Skušek. In one of them he hints at the dissolution of the Austro-Hungarian Empire after WWI and the possibility of his repatriation to Poland, which he refers to as his homeland. Franci Skušek's records mention that Kluge was an amateur archaeologist knowledgeable about Chinese history (Skušek n.d.). The letters seem to reveal two crucial aspects of Skušek's coin collecting-one pertaining to certain specimens that were deemed most valuable Chinese numismatic artifacts at the time, the other underlining the importance of Skušek's social life in his collecting practices, i.e. showing how Skušek and Kluge cooperated in assembling their respective numismatic collections, how they searched for valuable specimens, discussed them, and consulted experts, both Chinese and European, in order to confirm their authenticity and estimate their value. 


\section{Types of Coins Discussed by Kluge and Skušek}

Kluge's letters are sprinkled with mentions of ancient Chinese coins he considers most valuable in the world of Chinese numismatics. The remarkable coins from the Wang Mang period, for example, have always been most sought after among collectors of Chinese money, Kluge being no exception. Describing specific types of coins, he touches upon the Wang Mang coins several times. In a letter, dated February 15, 1919, he brings up two rare coins, as he writes:

Ich wollte Ihnen nämlich zusenden meine Schlüsselmünze mit dem goldenen "ein Messer" = "i dao" im Kopfe, dann eine andere, etwas verschiedene in Gestalt, die offenbar sehr viel Gold enthält.

I wished to send you my key-coin with the inscription yi dao, "one knife", in gold on the top part of the coin, and then another, rather different in shape, which obviously contains a lot of gold.

Based on the description he gives we can assume he is writing about coins from the Wang Mang period. With the interregnum period of Wang Mang, large, unique spade coins and knife coins, used in the second half of the Zhou dynasty, reappeared for a short while. Due to their large denomination and size, ornate and meticulous minting techniques, the content of gold or silver and, last but not least, their rarity, these coins are still among the most valuable numismatic artifacts worldwide today (Hartill 2017 [2005], 86-90). Knife coins from the period can sometimes be somewhat reminiscent of keys in shape and are occasionally referred to as "keycoins” (yaoshi bi 錀匙幣 or yaoshi qian 錀匙錢), which is also the expression used by Kluge. Indeed, three such key-coins (Schlüsselmünzen in German) from the Wang Mang period can be identified in Skušek's collection of coins as well as on the list, in the Summary, and the inventory book (figs. 10 and 11).
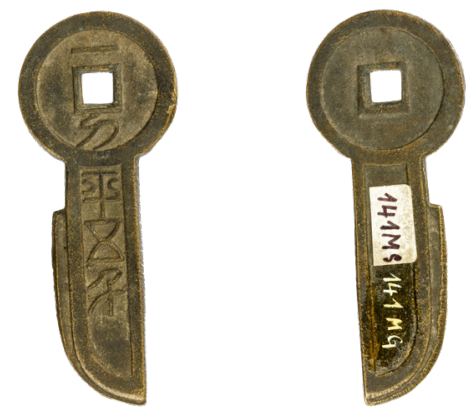

Figures 10 and 11. A specimen of the Wang Mang period "key coin" (the obverse and the reverse of the coin). Photo by Blaž Verbič. (Source: Skušek Collection, Slovene Ethnographic Museum, Ljubljana) 
Apart from the Wang Mang period coins, Kluge seems to cherish Song dynasty (960-1279) pieces in particular. For instance, he advises Skušek to buy Song dynasty coins as some of the most valuable specimens from Chinese imperial history, citing the dynasty, more specifically the Northern Song dynasty (960-1127), as "the most prominent dynasty in China's history in political, geographical and art-historical terms" (in der Geschichte Chinas die größte Dynastie in politisch, geographisch, und kunsthistorischer Beziehung) and as "a turning point in the history of Great China" (ein Markstein von Groß-China). In his letter, written on December 7, 1918, he continues about the coins from the period:

Aus diesem Grunde ist auch diese „nördl. Sung” Dynastie für den $\mathrm{Nu}-$ mismatiker die interessanteste, und ich muß sagen wohl auch wegen des Reichtums an Münzen, weil reich an Einheit und Größe, die leichteste, wenigstens für mich. Die hier, besonders im Norden der Stadt ausgegebenen Münzen sind fast alle aus dieser Dynastie. Oft werden mir ganze Stränge offeriert zum Kauf. - Trotzalledem bitte ich zu bemerken, daß die "nördl. Sung” ist und bleibt der Kernpunkt der chinesischen Geschichte, Kunst und Numismatik! Gestatten Sie, daß ich noch auf einen anderen Punkt bezüglich dieser Dynastie aufmerksam mache! Diese Bemerkung ist notwendig! In der Sung Dynastie sehen Sie, daß derselbe Kaiser Münzen prägen ließ mit verschiedenen Titeln, diese Titel sind stets der Regierungsname des lebenden Kaisers, nach dem die Chinesen die Jahre benennen. Die Kaiser wechselten oft nach einigen Jahren ihren Regierungstitel. Auch in anderen Dynastien kam das vor, doch seltener. Von der Sung Dynastie bis Ming Dynastie ist stets der Regierungstitel des Kaisers geprägt. Den geschichtlichen Namen bekamen diese Kaiser erst nach ihrem Tode mit dem hohen Ehrentitel "Tsung". (Kluge 1918)

That is why the "Northern Song" dynasty is the most interesting period also for numismatists, and, because of the richness of its coins, which are of large denominations and sizes, also the most pleasant to study, at least for me. Almost all the coins offered here, especially in the northern part of the city, originate from this dynasty. Often whole series of these coins are offered for sale. Nevertheless, we should bear in mind that the "Northern Song" dynasty is and remains the core of Chinese history, art and numismatics! Let me point out one more thing in relation to this dynasty! And this is important! In the Song dynasty, we notice that the same emperor had coins minted with different reign titles. These titles 
always refer to the reign title of the living emperor, after which the Chinese name the years. It was common for Song emperors to change their titles after a few years. This also happened in other dynasties, but less frequently. From the Song dynasty to the Ming dynasty, it was always the reign title of the emperor that was minted on the coins. It was only posthumously that the emperors obtained their historical names, which always contained the high honorary title of "Zong".

As Kluge correctly observes, cash coins ${ }^{5}$ from all the imperial dynasties were normally minted with the same reign title throughout the reign of an individual emperor, while it was not unusual for Northern Song emperors to change currency several times and name it after different periods of their reigns. With their meticulous fonts ${ }^{6}$ and minting techniques, these coins are much sought after and highly valued among numismatists (Hartill 2017 [2005], 125-59). Indeed, we notice no less than 19 Song dynasty coins cited on the list and on the Summary about Skušek's numismatic collection. They list cash coins issued by the following Northern Song dynasty emperors: Taizu 太祖 (r. 960-976) (one coin), Taizong 太宗 (r. 976-997) (two coins), Zhenzong 真宗 (r. 997-1022) (three coins), Renzong 仁宗 (r. 1022-1063) (three coins), Yingzong 英宗 (r. 1064-1067) (one coin), Shenzong 神宗 (r. 1068-1085) (three coins), Zhezong 哲宗 (r. 1085-1100) (one coin) and Huizong 徽宗 (r. 1100-1125) (five coins) (figs. 12-14).

5 Round cash coins with a square hole in the centre, fangkong qian 方孔錢, were an established form of currency from the Han dynasty (202 BC-220 AD) on. In 621, the Emperor Gaozu 高 祖 (reigned 618-626) of Tang (618-907) introduced a new standard, the so-called tongbao 通寶, which means the "currency in circulation" or simply denotes the currently valid coin (tong 寶 meaning "to circulate", "to be uniform" or “universal”, and bao 寶 meaning “wealth" or "money") (Cao 2014, 1-7; Hartill 2017 [2005], 103). Tongbao coins were minted in a wide range of variations and values in the following periods of Chinese history, as they remained the standard currency until the end of the Qing dynasty. The coins normally bore a four-character inscription arranged around the square hole, the two characters read from top to bottom denoting the title of the imperial reign (nianbao 年號), during which the coin was issued, while the tong 通 and bao 寶 characters are read horizontally from right to left. The whole inscription thus literally means "money in circulation at the time of the Emperor X". Song dynasty coins were somewhat special in this respect, as the four-character inscriptions on the obverse are sometimes read clockwise, starting with the character at the top and ending with the character at the left (Cao 2014, 15).

6 Apart from the regular script or kaishu 楷書, they used various scripts for the same types of coins, such as the seal script or zhuanshu管書, the “clerical script” or lishu隸書, the “grass script” or caoshu 草書 and the “running script” or xingshu 行書. 

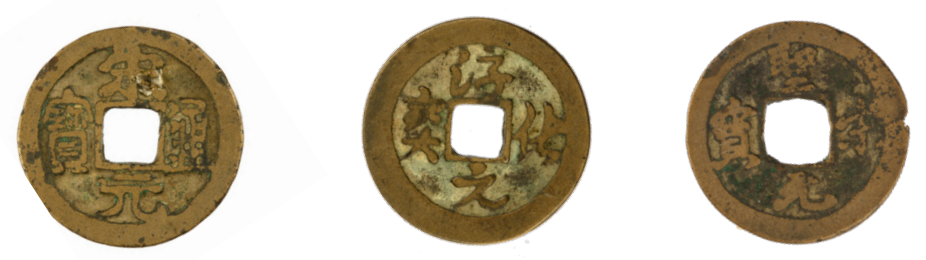

Figures 12-14. Northern Song dynasty coins. Photo by Blaž Verbič. (Source: Skušek Collection, Slovene Ethnographic Museum, Ljubljana)

Other letters by Kluge touch upon types of coins dating from periods of Chinese history even earlier than the Wang Mang interregnum. In the letter dated November 25, 1918, he writes about an entire collection of ancient Chinese coins that Skušek probably bought from him, and even mentions the prices of these items:

Für einen wirklichen Spottpreis erhalten Sie damit eine wissenschaftlich signierte Sammlung der markantesten chinesischen Münzen, sich erstreckend über einen Zeitraum von 3000 Jahren. Die Spatenmünze allein, die so rar ist, daß viele Numismatiker sie nur aus Abbildungen kennen, hatte vor dem Krieg z. B in Tsingtau den Mindestwert von 71/2 Dollar. Die Münzen vor Christus bis einschließlich Wang Mang in jeder der beiden Sammlungen haben mich selbst etwa 20 Dollar gekostet. (Kluge 1918)

For a ridiculous price, you can get a scientifically verified collection of some of the most striking Chinese coins from a period spanning over three thousand years. The spade coin alone is so rare that many numismatists know it only from illustrations - it would have fetched at least seven and a half dollars in Qingdao before the war. Coins from before Christ up to the end of Wang Mang ['s rule] in each of the two collections cost me some 20 dollars.

We cannot say with certainty what type of a spade coin Kluge refers to in this letter and from what period it originates. It is important to note that spade money was used during the Eastern Zhou dynasty, i.e. the Spring and Autumn Period (771-476 BC) and especially during the Warring States period (475-221 BC). At the time, Chinese bronze money came in various shapes, mostly as miniature bronze replicas of everyday objects (Saje 2002, 108-109).Three main types were 
most commonly used: coins shaped like a spade ( $b u$ 布) were used in the states of Zhou 周, Wei 魏, Han 漢 and Qin 秦, money in the shape of a knife (dao 刀) was used in the state of $\mathrm{Qi}$ 齊, while the states of Zhao 趙 and Yan 燕 first used knife money before switching over to spade coins. As already mentioned, spade coins reappeared during the Wang Mang period. Several different spade coins can be identified on the list, the Summary, and the inventory of Skušek's coins as well as identified in his collection. These include 16 specimens of "old spade coins" from the Zhou dynasty and four issued by Wang Mang. The coin mentioned by Kluge could thus be any of these items (figs. 15 and 16).
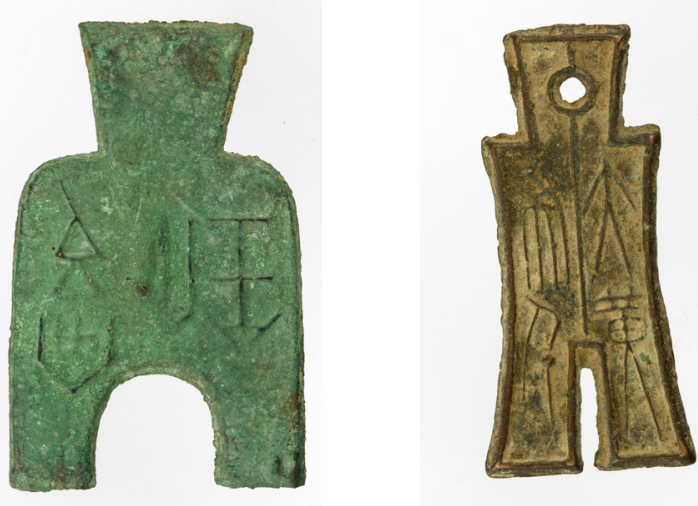

Figures 15 and 16. Two specimens of spade money. While the first coin originates from the Warring States Period (the state of Wei 魏, 425-344 BC), the second one is the famous "robe coin” from the Wang Mang period. Photo by Blaž Verbič (Source: Skušek Collection, Slovene Ethnographic Museum, Ljubljana)

Meanwhile, already in his first letter, dated Nov 17, 1918 Kluge advises Skušek to purchase a coin from the Western Han dynasty (Xi Hanchao 西漢朝) (206-24 BC):

... eine sehr schöne, große, echte Münze 37 vor Chr. zum Verkauf ausliegt, die ein wunderschönes Schaustück in Ihrer Sammlung wäre. Dieselbe ist rund und hat den Durchmesser von etwa $12 \mathrm{ctm}$. Diese Münze ist rar und ist genau in meinen Büchern verzeichnet. Doch der Mann will wenigstens 8,00 Dollar haben. Wenn ich Glück und Geld habe, hoffe ich dieselbe für 5,00 Dollar zu erstehen, wenn mir keiner zuvorkommt. Wenn Sie nun wünschen, daß ich diese schöne große Münze für Sie kaufe für 5 oder höchstens 6 Dollar, so bitte ich, mir bald zu schreiben. Es wäre ein schönes Gegenstück zu der großen 
"Gewandmünze", die Sie bereits besitzen; diese Ihre große "Gewandmünze" ist eine Münze des Usurpator kaisers "Wang Mang" von 9-23 nach Chr., die auch ein selten schönes Stück ist. (Kluge 1918)

... a beautiful, large, genuine coin dating from $37 \mathrm{BC}$ is available for purchase, and would be a wonderful showpiece for your collection. It is round, and has a diameter of approximately $12 \mathrm{~cm}$. This coin is rare and looks exactly as described in my books. The man wants at least eight dollars for it. With some luck and money, I could get it for 5 dollars, unless someone purchases it before me. If it is your wish that I buy this large and beautiful coin for you for 5 or at most 6 dollars, please write to me soon. It would be a nice stand-out piece along with the large "robe coin" [spade-coin] that you already own, which is a coin of the usurper Wang Mang, of AD 9-23, and also an extraordinarily beautiful specimen.

The coin Kluge is describing is most likely a wuzhu 五銖 (“five grain") coin issued in the late 1st century BC, but the size of $12 \mathrm{~cm}$ is too large, while $12 \mathrm{~mm}$ would be too small. We find this piece listed in all the above mentioned sources pertaining to the collection of coins Skušek brought to Ljubljana, but cannot identify the piece itself. Further, the excerpt mentions another coin that can be found in Skušek's collection - the already mentioned spade coin, or "robe coin", as Kluge names it. Spade coins from the Wang Mang period are somewhat reminiscent of small robes in their shape, which is why they are sometimes referred to as "robe coins" (bu 布in buqian 布錢 also meaning “cloth" in Chinese).

In a letter dated December 15, 1918 Kluge brings up yet another rare coin type:

Vor drei Tagen habe ich Ihnen Ihre schönen Münzen signiert zugesandt, habe auch einige seltene Exemplare hinzugefügt einerseits aus Dankbarkeit, anderseits in der stillen Hoffnung, von Ihren drei sehr schönen Spatenmünzen ein Exemplar z.B. das am Kopfe beschädigte und von Ihren vielen Geisterkopfmünzen eine oder andere erhandeln zu können. Die letzteren Münzen war ich erstaunt zum ersten Male in Wirklichkeit zu sehen, auch diese massive Sorte der Spatenmünzen waren mir neu. (Kluge 1918)

Three days ago, I sent you your beautiful coins examined and verified, and also sent some rare specimens, on the one hand out of gratitude, and on the other hand in quiet hope that I might obtain one of your three splendid spade-coins, for example the one damaged on the obverse, and one of your ghost-face [ant-nose] coins. I was astonished to see the latter for real for the first time, while this massive kind of spade-coins was new to me as well. 
Kluge again mentions Skušek's spade coins, although we cannot say with certainty whether these are the coins included in Skušek's collection as we know it today. The other type of coins, mentioned in the excerpt, are the aforementioned "ant-nose" or "ghost-face coins", more than 20 of which can be identified in Skušek's collection and all the newly found documents (figs. 17 and 18). This type of money was used in the state of Chu 楚 during the Warring States Period and is considered an utmost rarity in the world of Chinese numismatics (Hartill 2017 [2005], 1-79).
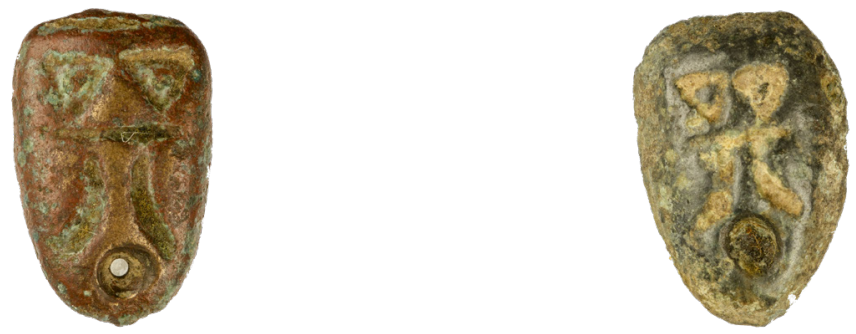

Figures 17 and 18. Two specimens of the rare "ant-nose money" or "ghost money" (the obverse). Photo by Blaž Verbič. (Source: Skušek Collection, Slovene Ethnographic Museum, Ljubljana)

Kluge's letters thus provide insight into the types of coins popular among collectors of Chinese money at the time. Despite a few historical inaccuracies that we encounter in his writing, we can assume that he had quite a good grasp of Chinese history and numismatics. The types of coins he mentions as worth collecting are still considered some of the rarest, most valuable and sought-after Chinese numismatic artefacts today. Further, the letters also give us a glimpse of the collecting practices among foreigners who were staying in East Asia at the time. More specifically, they reveal Skušek's way of collecting objects.

\section{Ivan Skušek's Practice of Collecting Chinese Coins}

Until the discovery of the supplementary material, we did not know how exactly Skušek collected these coins. The combination of the list in German, the Summa$r y$ in English, and the letters from Kluge reveal Skušek to have been a systematic collector who paid attention not only to the provenance, history and significance of each item, but also to its authenticity. How was Skušek able to assemble this collection? Where did he acquire his knowledge of Chinese coins and other types 
of Chinese antiquities? The letters by Kluge show us that the answer is to be found in his social life in Beijing.

The notes written by Franci Skušek throw light on his brother's life in Beijing. With these notes and general knowledge about foreigners in Beijing at that time, we can imagine the environment in which Ivan Skušek Jr. put together his collection. As an officer of the defeated army, Skušek was probably taken from Qingdao to the diplomatic quarter in Beijing, which was situated within the city walls, close to the Forbidden City, the imperial walls, the commercial Hadamen Road ( $\mathrm{Ha}-$ damen 哈德門) and the walls of the “Manchu town”. After the Opium Wars and until 1911, most of the powerful Western forces had established their legations in this quarter, including Great Britain, Germany, Austro-Hungarian Empire, Belgium, Spain, the USA, France, Italy, Japan, the Netherlands, Russia, Sweden, Portugal, Denmark and Brazil. Life in this part of the city was entirely different from the everyday reality beyond its walls, where local Chinese lived. The quarter provided an abundant and diverse social life with numerous banquets, sports competitions, receptions and so on, and included two hospitals, a number of schools, banks, hotels, parks and a polo pitch, churches, customs and post offices, a police station, various other buildings and military barracks. During WWI, the German military barracks were transformed into a camp, where Skušek and his fellow officers were taken (Čeplak Mencin 2012, 103-104).

Despite being in confinement, the German and Astro-Hungarian officers were still privileged to some extent. Ivan Skušek was allowed to exit the camp at any time, move freely around Beijing, and enjoy the colourful social life in the foreign quarter. We know from Kluge's letters that he was an employee of the Dutch Legation at the time, which in turn would explain how he had access to the highest circles of foreigners living in the diplomatic quarter as well as how he acquired the financial resources to buy antiques and was able to store them appropriately. And perhaps even more importantly, it was probably at that time that he become acquainted with numerous interesting, learned and influential people. For example, according to his brother's records, Ivan Skušek knew Sir Reginald Fleming Johnston (1874-1938), the English teacher of the last Chinese emperor, Puyi 溥 儀 (1906-1967, ruled 1908-1912), and the only foreigner allowed into the Imperial Palace (Skušek n.d.). It was most likely through his social connections that Skušek purchased numerous Chinese antiquities, probably not just from Chinese, but also from Europeans (Čeplak Mencin 2012, 103-105). Maurus Kluge must have been among the people Skušek met in Beijing. The letters Kluge wrote to Skušek do not say when or how exactly the two met, however, they are very eloquent of the ways they helped each other with their numismatic collections and reveal Kluge to be quite an expert in Chinese history. As we have seen, Kluge's 
letters provide a detailed insight into the collecting trends in the realm of Chinese numismatics of the time, while they also speak volumes of Ivan Skušek's collecting practices as well.

What we can observe in the letters is that Skušek and Kluge exchanged entire collections and individual coins and consulted other experts for assessment, authentication and verification of each item. It is obvious that Kluge also advised Skušek on what to collect and educated him on Chinese history. As we have seen, for example, he advised him to buy Wang Mang and Song dynasty coins as some of the most valuable items. In his first letter (at least the first one of those we have), dated November 17, 1918, immediately after the war, Kluge writes about a collection of numismatic charms as well as two collections of coins he had sent, or was going to send, to Ivan Skušek:

Vor einigen Tagen sandte ich an Sie die Amuletten-Sammlung. Ich nehme an, daß Sie dieselbe richtig erhalten haben und hoffe, daß dieselbe Ihnen gut gefällt. Diese Tage, wo hier Siegesferien waren habe ich nun auch die beiden Münzensammlungen fertiggestellt und sind dieselben versandfertig. Ich will dieselben jedoch erst absenden, nachdem ich die $\mathrm{Na}$ (ch)richt von Ihnen erhalten habe, da ich nicht weiß, wie jetzt der Hase läuft. Bitte schreiben Sie mir gütigst, ob ich dieselbe abschicken soll, denn ich glaube, unter den jetzigen traurigen Umständen für uns ist mein Weihnachtsbesuch im Lager zum wenigstens sehr zweifelhaft. (Kluge 1918)

I sent you a collection of amulets a few days ago. I suppose you have received it by now and I hope you like it. In the past few days, when we've been having a victory celebration holiday here, I have prepared both coin collections and they're ready for shipment. I won't send them until I receive a message from you, since I am not acquainted with how things stand now. Please notify me if I should send them, for I think that in the present unfortunate circumstances, my Christmas visit to the camp, if nothing else, is at least questionable.

The following letters reveal that Kluge not only advised Skušek, but also sent him coins to be assessed and verified by Skušek's "Chinese confidant". At this point, we learn from the letters that Skušek had a knowledgeable Chinese acquaintance who checked and verified the authenticity of the coins. Kluge calls him "Your confidant" (Ihr-Gewährsmann) or "Your Chinese coin expert" (Ihr chinesischer Münzenkenner) and confirms in his letter dated January 24, 1919 that the Chinese confidant is certainly very knowledgeable and can be trusted: 
Ihr Gewährsmann hatte ganz recht und ich bin jetzt überzeugt, daß er die chinesische Numismatik sehr gut versteht und daß Sie seinen Angaben unbedingt Glauben schenken können. (Kluge 1919)

Your confidant was absolutely right, and I am now convinced that he understands Chinese numismatics very well and that you can trust his opinion completely.

In the same letter, he writes about an exceptionally old and rare coin, asking for some more help from Skušek's "confidant". From the point of view of today's Chinese numismatics, we cannot be certain about the historical accuracy of his description and dating of the coin. However, the excerpt from the letter still provides an invaluable insight into the nature of the two enthusiasts' cooperation on their numismatic collections:

Als Dank für die vielen mir erwiesenen Liebenswürdigkeiten bitte ich Sie eine sehr alte, echte Münze, welche wohl ganz richtig der Dynastie Hsia 2205-1766 vor Chr. zugeschrieben unter dem Kaiser Yü 22052197 vor Chr. Die Zeichen, reine Urzeichen der chinesischen Schrift, sind unleserlich, es sei denn, daß Ihr Gewährsmann dieselben lesen kann. Bitte zeigen Sie ihm diese Münze und schreiben Sie mir, was er davon halte. Das ist die schwarze Münze, von der ich Ihnen sagte, daß dieselbe Ihnen noch fehlt. - Dieselbe wird betrachtet als eine aus der ältesten Münzperiode Chinas. Ich bin sehr neugierig, was Ihr chinesischer Münzenkenner darüber sagen wird und ob er die Zeichen wird lesen können. (Kluge 1919)

In gratitude for your many kind gestures, I offer you a very old, genuine coin, rightly attributed to the Xia dynasty (2205-1766 BC) and the reign period of Emperor Yu (2205-2197 BC). The markings, genuine antecedents to the Chinese script, are illegible unless your confidant can read them. Please show him this coin and let me know what he thinks of it. It is the black coin that I told you about and that you were still missing. This coin belongs to one of the oldest periods of Chinese coins. I am very curious what your Chinese coin expert will have to say about it and whether he will be able to read the markings.

The earliest coins in the Skušek collection date from the second half of the Zhou dynasty, i.e. the Spring and Autumn Period and particularly the Warring States Period. Meanwhile, no coins have been attributed to the Xia dynasty. The old, black piece described by Kluge has not been found in Skušek's collection, and is 
not mentioned in any of the three references to the collection (the list, the Summary, and the inventory book). However, what is important in this excerpt is the way both Skušek and Kluge sought for sources of knowledge on Chinese coins. It is true that early pieces of Chinese money bore inscriptions in the seal script ( $z h u-$ anshu管書), which is very difficult for non-experts to read, therefore, they needed the help of Skušek's Chinese expert.

In a subsequent letter, dated February 15, 1919, Kluge similarly writes about the aforementioned knife coin from the Wang Mang period, as he cannot confirm its authenticity himself:

Ich glaube fast, es sind die Münzen, von denen Ihr Gewährmann sagt, es gibt eine falsche und eine echte. Wenn ich hier bleibe, sende ich Ihnen dieselben zur Ansicht zu, einerseits, um ein Urteil von maßgebender Seite zu hören, dann aber besonders, um Ihre Sammlung durch in die Fugen fallende, markante Stücke eventuell zu bereichern. Die goldhaltige Münze besitze ich schon lange, wurde aber erst nach meiner letzten Rückkehr von Peking auf dieselbe wegen ihres angeritzen Goldglanzes und der abweichenden Form aufmerksam, besonders da Ihr Gewährsmann gesagt hat, es gibt eine falsche und eine echte davon. Also, bitte, zuerst teilen Sie mir den Empfang u. die Begutachtung der empfangenen Münzen mit, dann werden wir des Näheren über weitere markante Münzen ehrlich und kameradschaftlich verhandeln. (Kluge 1919)

I am certain that these are the coins your confidant mentioned, where one is fake and the other genuine. If I stay here, I will send them to you for inspection, on the one hand to hear an expert opinion, but especially to enrich your collection, in case that is possible, with remarkable pieces. I have owned the gold coin for a long time, but I started paying more attention to it after my last return from Beijing because of its inlaid gold and unusual shape, especially since your confidant had said there was one fake piece and one genuine specimen. Therefore, I would like to ask you first of all to confirm that you have received the coins and inform me about the expert assessment of them, then we can negotiate and discuss these remarkable coins in detail and in an honest, friendly manner.

The letters Kluge wrote to Skušek thus give us a thorough insight into how they chose Chinese coins for their collections, systematically checking authenticity and provenance for each item, and, more broadly, also into Skušek's collecting practices in general. We do not have similar documents that would reveal his correspondences with other collectors, connoisseurs and experts with regard to other 
categories of collectibles. Nonetheless, based on the letters from Kluge, we can assume that he took a similarly systematic, careful approach to collecting other types of objects. His collecting practices were probably closely related to his social life in Beijing, as he must have assembled objects for his collection with the help and advice from the various learned people he met there.

Apart from the background of some rare pieces in Skušek's collection and the cooperation between Skušek and Kluge, the letters also reveal the circumstances of that time. Both collectors came to China from the Austro-Hungarian Monarchy, from the South-East and East European periphery, Skušek from Slovene and Kluge from Polish ethnic territory. It is possible that a shared origin connected them even more closely than their collecting. After WWI and the dissolution of the Austro-Hungarian Empire, they both faced the threat of repatriation, as evident from Kluge's letters. In the letter dated February 15, 1919, he speculates about this issue:

Ich habe zwar schon die Ordre erhalten, vor dem 28. d. M. in Shanghai zu sein, doch werde ich wohl hier bleiben, da nach einem vorgestrig abendl. Telegramme an unsern Bischof mein Name bereits auf der Liste steht für "recommanded for exemption" seitens der italienischen Gesandtschaft. Darnach werde ich wohl hierbleiben. Mir persönlich ist eins wie's andere recht! (Kluge 1919)

I have already received the order to be in Shanghai by the 28th of this month. However, I will probably stay here, since a telegram to our bishop the evening before yesterday had my name on the list of those "recommended for exemption" in the Italian Legation. Therefore, I will most likely stay here. Personally, I am all right with either way.

In the following letter, written five days later, on February 20,1919, he happily writes to Skušek:

Ich bin von der Repatriierung d. 17. d. M. auf Betreiben unseres Gouverneurs mit Empfehlung der italienischen Gesandschaft dispensiert worden. Sie bleiben natürlich als Beamter der holl. Ges. auch. Wie ist es mit Herrn Gayer? Hoffentlich bleibt er auch. So können wir weiter wegen Münzen sprechen. (Kluge 1919)

On the 17 th of this month, I was exempted from repatriation at the instigation of our governor and with the recommendation of the Italian Legation. As an official of the Dutch Legation, you will of course stay as well. What is the situation with Mr. Gayer? Let us hope he stays too. Then we can keep talking about coins. 
Mr. Gayer and several other of Skušek's subordinate officials were indeed repatriated. Twelve days later, on March 4, 1919, Kluge writes:

Nun weiß ich, daß Sie wohlauf sind, aber mit Arbeit zu sehr überladen. Wie werden Sie allein die Unmenge von Arbeit schaffen, wo Ihnen die beiden Unterbeamten genommen sind? Das viele Sitzen, Schreiben und Rechnen ist oft kein Spaß! Sie werden die ganze Arbeit sicherlich schaffen, doch ich fürchte mit einiger Benachteiligung Ihrer Gesundheit. (Kluge 1919)

Now I know you are healthy but overloaded with work. How will you be able to manage the vast amount of work, when both of your subordinate officials have been taken away from you? So much sitting, writing and doing accounts is no joke! You are certainly capable of doing all the work, albeit, I fear, with consequences for your health.

Neither of the two men was repatriated at the time. But with the repatriation of many others around them, both of them faced changes. Skušek married Tsuneko, went to Japan with her and then returned to Ljubljana with his new family. Maurus Kluge remained in Taiyuan until 1923, when he was appointed rector of the Siberian seminary in Harbin. In 1926, he returned to Europe, and died on September 25, 1927, in Breslau/Wroclaw. ${ }^{7}$

Ivan Skušek, Tsuneko and her two children left for Europe in June 2020. They took a train from Beijing to Tianjin, where they boarded a Chinese ship, sailed to Nagasaki, boarded a Japanese ship, sailed further to Singapore, and from there across the Indian ocean to Aden, across the Red Sea, through Suez to the Mediterranean. Having finally reached Trieste, they took a train to Ljubljana, where they arrived on September 8, 1920 (Čeplak Mencin 2012, 111). Ivan Skušek returned home after seven years in East Asia and brought a family with him. A little more than a month later, a number of crates full of curious, precious objects arrived: Ivan Skušek's impressive collection, including its numismatic part.

\section{Conclusion}

Although specific to Skušek's coin collecting, the letters from Fr. Maurus Kluge tell us how such a rich, extensive, systematic, and in every way representative collection of East Asian objects came into being. In other words, Kluge's letters give

7 Personal correspondence with Dr. des. Thomas Richter, director of the Internationales Katholisches Missionswerk library, November 2020. 
us an insight not just into the process of building Skušek's numismatic collection, but also into his collecting methods in general. It is very likely that he consulted several experts and connoisseurs for the various types of objects he was interested in, just as he did with the coins.

Skušek's wish to make his Chinese antiquities and curiosities available to the general public is clear from his decision to leave the collection to the National $\mathrm{Mu}-$ seum after his death. He believed that the museum would be able to appreciate and preserve it, as well as ensure it would be presented appropriately to the public. Ivan Skušek Jr. died in 1947, and his collection formally passed into the possession of the National Museum of Slovenia in 1950. The collection remained in the Skušeks' apartment, with Tsuneko appointed the honorary custodian. After her passing in 1963, the collection was moved to the National Museum, which then handed it over to the Slovene Ethnographic Museum in 1964. In the following years it was partly inventoried by Dr. Pavla Štrukelj. The Ethnographic Museum opened a branch unit at the Goričane Baroque mansion, the so-called Museum of Non-European Cultures, where it installed a permanent exhibition of Skušek's collection. The inventory of 216 coins from the collection suggests that these specimens were kept on 15 separate boards or tables (one to 17 coins per table), possibly as part of the permanent exhibition at the Goričane Mansion (Berdajs 2021). This is supported by the handwritten numbers on papers associated with distinct groups of coins. The exhibition remained open until 1990, when restoration work on the mansion started. The Skušek collection, including the numismatic assemblage, has been kept in the museum stores at Metelkova Street in Ljubljana ever since (Čeplak Mencin 2012,117). With the exception of a temporary exhibition, Encounters with China-200 Years of Slovenes Discovering Chinese Culture, curated by Ralph Čeplak Mencin and displayed at the Slovene Ethnographic Museum in 2006, the majority of objects have remained in the museum stores. Therefore, one of the aims of the VAZ project is to thoroughly research and reconstruct Ivan Skušek Jr.'s collection. With the discovery of the lists of objects, previously believed to have been lost, that research has been made much easier, especially as far as the numismatic part of the collection is concerned.

The list of Skušek's coins, typed in German, includes pencil notes and corrections in Fr. Maurus Kluge's handwriting, which suggests that it was prepared or at least obtained by him. The fact that the inventory book by Dr. Strukelj lists 216 coins, with the first 123 coins corresponding exactly to the ones listed in the Summary document, suggests that Strukelj still had the Summary and the list of coins available. It is important to note that these 216 coins are most likely only part of Skušek's entire collection of Chinese coins. Starting in 2020, I have been working together with the curator Ralf Čeplak Mencin and so far have fully examined and 
photographed about 900 new coins. These include some Ming dynasty (13681644) coins, while the majority of coins originate from the Qing dynasty, particularly from the Qianlong 乾隆 period (1735-1796) (Qianlong tongbao 乾隆通 寶). We even discovered more than 50 Japanese coins with the inscription Kan'ei tsūho 寛永通寶, issued during the Edo period (1603-1868), which are known to have been present in certain parts of China during the Qianlong period (Feng and Wang 2003 [1980]). Although these curious coins are not listed in the existing inventory or the list of Skušek's coins, it is likely that they belonged to him. In short, the exquisiteness, rarity and value of the coins, both those proven to be part of his collection and those possibly having belonged to him, once again confirm Skušek as an exceptional collector and connoisseur.

Even Kluge's letters to Skušek reveal how highly the missionary thought of Skušek as an acquaintance and fellow collector. One of the letters, dated February 15, 1919, reads:

Glauben Sie mir, Sie sind im Besitze einer sehr respektablen Sammlung chinesische Münzen. (Kluge 1919)

Believe me, you are in possession of a very respectable collection of remarkable Chinese coins.

Indeed, Kluge might have been one of the first people to notice and respect Skušek's insight, curiosity, enthusiasm and open mind, as well as his vision of presenting China to his fellow countrymen. In his last letter, written on December 31, 1919, in which he also wishes him a "a Happy New Year from the bottom of my heart" (wünscht von Herzen ein glückliches Neues Jahr), he praises him as follows:

Sie sind ein großer, hell- und weitsehender Prophet! (Kluge 1919)

You are a great visionary and a farsighted prophet!

And that indeed is what Skušek was-an outstandingly progressive and foresighted man of remarkably broad horizons and great vision. He can rightly be considered the first collector of Chinese objects in the Slovene ethnic space to have built his collection systematically, researching and verifying the background of each object while also keeping a detailed list of his purchases. His collecting zeal and methods clearly reflect his goal of establishing a private museum where the collection would be on display for his fellow Slovenes to see. His extraordinary legacy remains to be studied more deeply by experts, not least its impressive numismatic assemblage. 


\section{Acknowledgements}

The research for this paper was carried out as part of the project East Asian Collections in Slovenia: Inclusion of Slovenia in the Global Exchanges of Objects and Ideas with East Asia (2018-2021) (no. J7-9429), funded by the Slovenian Research Agency.

The research into Ivan Skušek Jr.'s numismatic collection and related materials was possible with the help from Dr. Helen Wang, Curator of East Asian Money at the British Museum, Mag. Ralf Čeplak Mencin, Curator of Asia and Oceania at the Slovene Ethnographic Museum, and Lect. Mag. Niko Hudelja from the Department of History at the Faculty of Arts, University of Ljubljana.

\section{References}

Berdajs, Tina. 2021. "Retracing the Footsteps: Analysis of Lists, Inventories, and Photographs of the Skušek Collection from 1917 to 1950." Asian Studies 10 (3): 141-66.

Cao, Qin. 2014. "An Introduction and Identification Guide to Chinese Qing Dynasty Coins." Money and Medals Network website. http://www.moneyandmedals.org.uk. Accessed October 31, 2019.

Čeplak Mencin, Ralf. 2012. V deželi nebesnega zmaja: 350 let stikov s Kitajsko. Ljubljana: Založba/*cf.

Dessein, Bart. 2014. "Faith and Politics: (New) Confucianism as Civil Religion." Asian Studies 2 (1): 39-64. Doi: https://doi.org/10.4312/as.2014.2.1.39-64. Feng, Zuozhe 冯佐哲, and Wang Xiaoqiu 王晓秋. 2003 [1980]. “Azuma kagami and Wuqi jing bu: Historical Evidence of Sino-Japanese Cultural Interaction." Translated by Joshua F. Fogel. Sino-Japanese Studies. Accessed July 30, 2020. https://chinajapan.org/articles/01.2/01.2.28-40fengwang.pdf.

Hartill, David. 2017 [2005]. Cast Chinese Coins: A Historical Catalogue. London: New Generation Publishing.

Hrvatin, Klara. 2021. "The First "Mrs. Japanese" of Slovenia between the Two World Wars: Marija Skušek and Her Series of Lectures on Japanese Women." Asian Studies 10 (3): 169-97.

Jankowski, Lyce. 2018. Les amis des monnaies. La sociabilité savante des collectionneurs et numismates chinois de la fin des Qing. Paris: Editions Hémisphères.

Kluge, Maurus. 1918-1919. Letters to Ivan Skušek Jr. Translated by Niko Hudelja (2020). Taiyuan. (Unpublished manuscripts; the originals are kept by the Library of the Slovene Ethnographic Museum.) 
Marinac, Bogdana. 2017. Čez morje na nepoznani Daljni vzhod: potovanja pomoršcakov avstrijske in avstro-ogrske vojne mornarice v Vzhodno Azijo. Piran: Pomorski muzej.

Motoh, Helena. 2021. "Living Room Museum-Accommodating an Early 20th Century East Asian Collection in Lived Spaces." Asian Studies 10 (3): 119-40.

Saje, Mitja. 2002. Starodavna Kitajska: zgodovina Kitajske od najstarejših časov do dinastije Qin. Ljubljana: Oddelek za azijske in afriške študije Filozofske fakultete.

2004. Zadnja dinastija in izzivi sodobnosti: Zgodovina Kitajske od vdora Mandžurcev do ustanovitve Ljudske republike. Ljubljana: Znanstvena založba Filozofske fakultete.

Skušek, Franci. n. d. Rokopisni zapiski Francija Skuška Skušek. Unpublished manuscript; the original is kept by the Library of the Slovene Ethnographic Museum.

Summary of Mr. I. Skušek's Numismatic Collection Of Chinese Coins, to be Sold Eventually. 1946. Ljubljana. Unpublished document; the original is kept by the Library of the Slovene Ethnographic Museum.

Vampelj Suhadolnik, Nataša. 2019. "Zbirateljska kultura in vzhodnoazijske zbirke v Sloveniji." In Procesi in odnosi v Vzhodni Aziji: zbornik EARL, editors Andrej Bekeš, Jana S. Rošker, and Zlatko Šabič, 93-137. Ljubljana: Znanstvena založba Filozofske fakultete Univerze.

- 2020. "Ivan Skušek ml. kot zbiratelj kitajskega pohištva." Ars and Humanitas (Ideologije in prakse zbiranja in razstavljanja) 14 (2): 45-60. Doi: https://doi. org/10.4312/ars.14.2.45-60.

Visočnik Gerželj, Nataša. 2021. "Dancing with the Fan: The Role and Value of a Japanese Fan and Kimonos in the Transmission of Japanese Culture by Marija Tsuneko Skušek." Asian Studies 10 (3): 199-221.

Wang, Helen. 2012. "A Short History of Chinese Numismatics in European Languages." Early China 35 (36): 395-429. Accessed November 26, 2020. doi: $10.1177 / 24392412$.

Yu, Liuliang, and Yu Hong. 2004. Chinese Coins: Money in History and Society. San Francisco: Long River Press. 